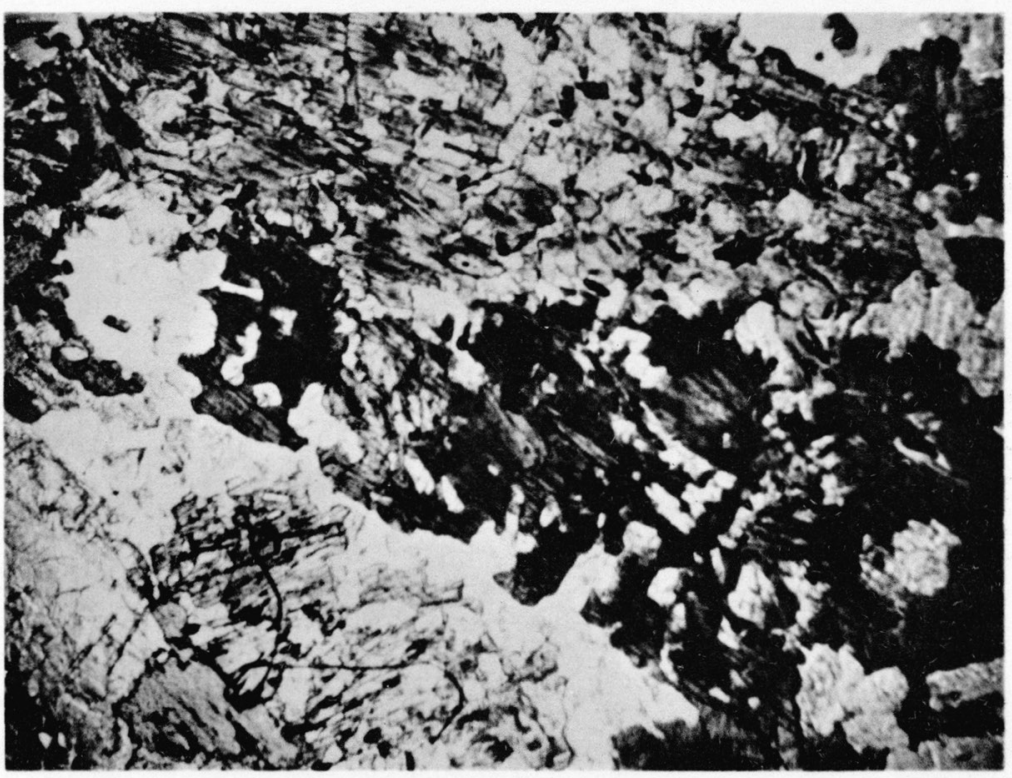

Figure 1. Gabbro at Contact with Tonalite

Poikilitic crystals of hornblende (dark) enclose andesine. Without analyzer (x 25).

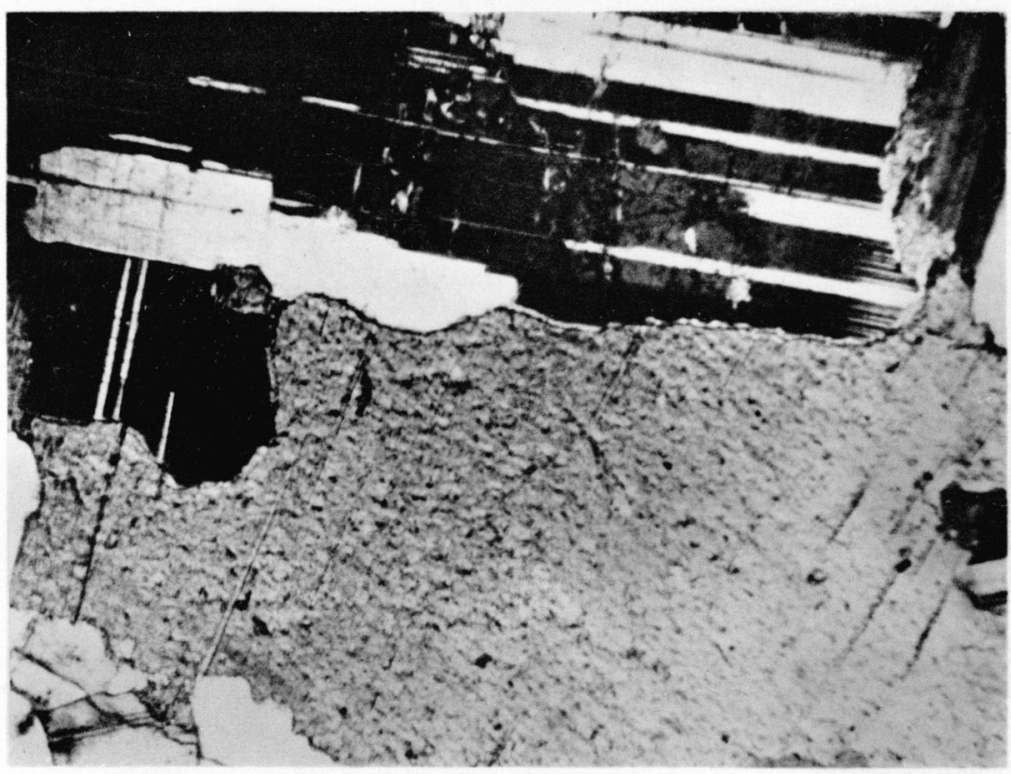

Figure 2. Tonalite

Tongue-like projections of biotite cut andesine. Crossed nicols (x 80). 


\title{
STRUCTURAL PETROLOGY OF THE VAL VERDE TONALITE, SOUTHERN CALIFORNIA
}

\author{
BY E. F. OSBORN
}

CONTENTS

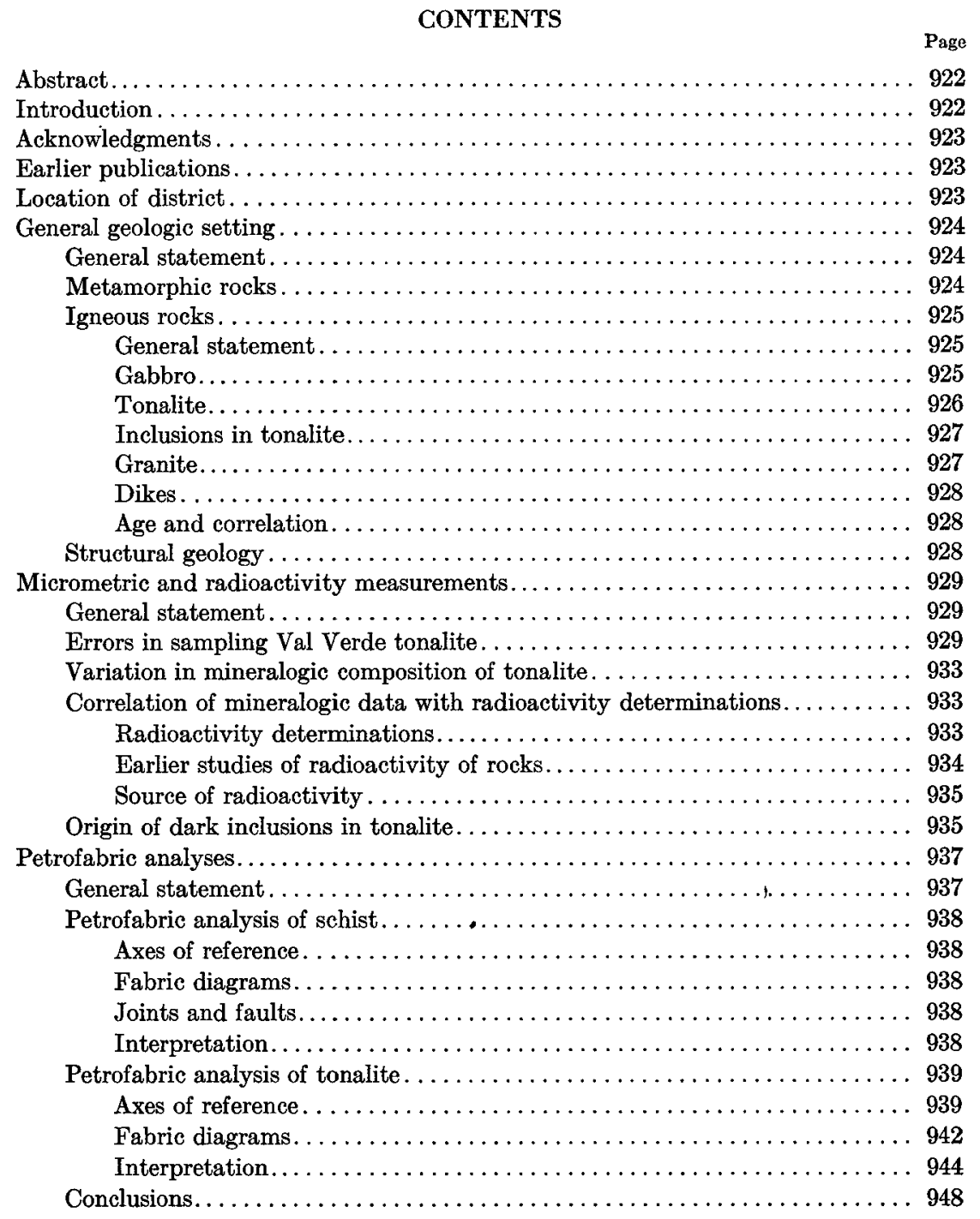


1. Map showing location of Val Verde district...................................

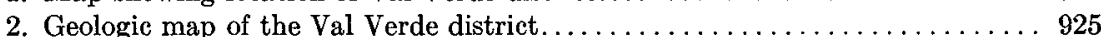

3. Graph of variation in mineral composition of tonalite............. 932

4. Graphs of albite content of plagioclase and radioactivity of tonalite . . . . . 934

5. Diagrams illustrating relation of axes of reference to dimensional orientation of

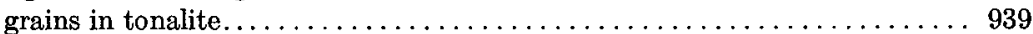

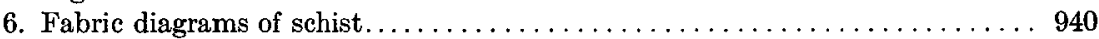

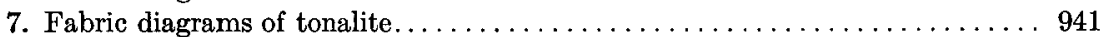

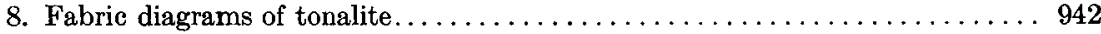

9. Fabric diagrams of tonalite and an inclusion. . . . . . . . . . . . . . 943

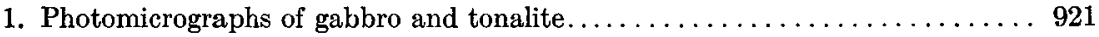

2. Photomicrographs of tonalite. . . . . . . . . . . . $\ldots 26$

3. Hand specimen oriented with respect to axes of reference........... 927

\section{ABSTRACT}

Micrometric analyses of the Val Verde tonalite were made on samples taken along a line extending from the border of the intrusive to a point 5 miles out in the intrusive. An attempt was made to evaluate sampling errors and to determine variation in mineralogic composition and radioactivity. The border of the intrusive was found to be more sodic and higher in radioactivity than the central part, and this is thought to be due to assimilation of quartz-biotite schist.

Inclusions in the tonalite are believed to be xenoliths of gabbro and quartzbiotite schist.

Petrofabric analyses of the schist country rock and the tonalite indicate that: (1) the schist was deformed primarily by rotation of mineral grains about a horizontal axis; (2) during intrusion of the tonalite a gneissoid structure developed in it parallel to the contact with the country rock with a linear element lying in the plane of foliation and paralleling the dip; (3) later stresses directed parallel to the strike of the foliation caused rotation of mineral grains in the tonalite about an axis parallel to the dip. The orientation of the minerals in the tonalite is thus believed to be due to a combination of magmatic flow and post-magmatic deformation.

\section{INTRODUCTION}

Two phases of the problem of batholiths and their origin are of special interest. The first concerns variation in composition of intrusive bodies, and the second deals with the origin and interpretation of primary flow structure. A unique opportunity to investigate these problems as applied to one intrusive was furnished by the construction of the Val Verde tunnel, one of a series composing the Colorado River Aqueduct which will carry water from Parker Dam on the Colorado River to Los Angeles and vicinity.

For slightly over 5 miles this tunnel passes through an apparently uniform tonalite intrusive at nearly right angles to the strike of the flow structure in the mass, and crosses the contact between the tonalite and quartz-biotite schist. The tonalite was examined along the line of the 
tunnel for variations in mineralogic composition and radioactivity; petrofabric data were obtained from oriented specimens in an attempt to determine the origin of the gneissoid structure.

\section{ACKNOWLEDGMENTS}

The study was made possible by the friendly cooperation of the Metropolitan Water District of Southern California and of Mr. R. W. Remp, general manager for the Dravo Contracting Company. The problem was suggested by Professor Ian Campbell, who gave helpful advice throughout the investigation. Dr. J. R. Schultz, Mr. Cooper Hyde, and Mr. Ygnacio Bonillas, III, assisted the writer during part of the tunnel mapping. Dr. H. W. Fairbairn, Dr. James Gilluly and Dr. Earl Ingerson offered valuable suggestions on petrofabric procedure and interpretation. The radioactivity measurements were made by Dr. R. A. Clarke and Mr. F. H. Wright of the California Institute of Technology. The writer is indebted to Professor Ian Campbell, Dr. James Gilluly, Professor J. T. Stark, Professor C. H. Behre, Jr., Professor Adolph Knopf, and Dr. Earl Ingerson for their criticisms of the manuscript.

\section{EARLIER PUBLICATIONS}

The general geology and physiography of the Perris Block, of which the Val Verde district is a small part, are discussed in papers by Dudley (1935 and 1936). The heavy accessory minerals of the Val Verde tonalite have been described by Wilson (1937). In some of the early reports of the California State Mining Bureau (Fairbanks, 1892; Goodyear, 1888), and in a paper by Waring (1919), very general descriptions of the geology of this region are given. The surface along the line of the Val Verde tunnel was mapped by Ransome (1932) and Buwalda for the Metropolitan Water District of Southern California. Professor Larsen and students of Harvard University are engaged in field work in surrounding districts. Some of the results of their studies are referred to below.

\section{LOCATION OF DISTRICT}

The railroad station of Val Verde, from which the tunnel is named, is located in Riverside County, California, 12 miles south of the town of Riverside. Beginning about a mile south of Val Verde, the tunnel extends for 7 miles N. $88^{\circ} \mathrm{W}$. A strip of country extending about 3 miles on each side of the tunnel was mapped. This area of approximately 45 square miles occurs within the Riverside quadrangle of the Topographic Atlas of the United States. The location of the Val Verde district with respect to the principal structural features of southern California is shown in Figure 1. 


\section{GENERAL GEOLOGIC SETTING}

GENERAL STATEMENT

The Val Verde district is part of a conspicuous topographic unit in southern California, named by English (1926, p. 54) the Perris Fault

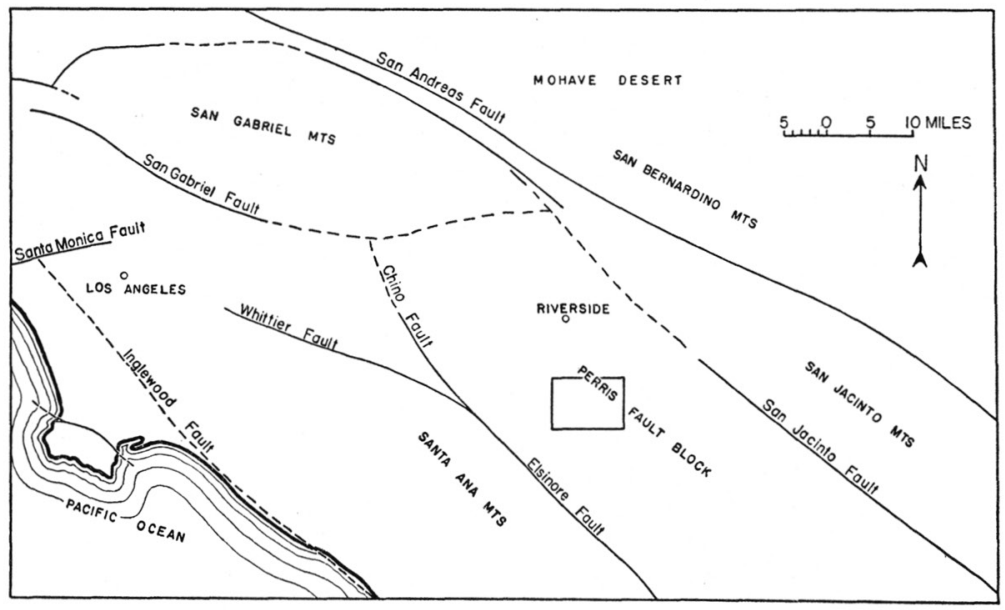

Figure 1.-Map showing location of Val Verde district

(From map prepared by W. A. English, 1926, U. S. Geol. Survey, Bull. 768)

Block. This unit is approximately 20 miles wide, bounded on the west by the Elsinore trough and on the east by the San Jacinto fault zone; it is of indefinite length, extending northward to the base of the San Gabriel Mountains and southward for some tens of miles. The region is one of relatively low relief, having an average elevation of about 1700 feet above sea level. The dominant rocks of the Val Verde district are medium-grained igneous rocks which have been intruded into a Triassic metamorphic series.

\section{METAMORPHIC ROCKS}

The oldest rocks in the Val Verde district are metamorphosed sediments, named by Dudley (1935, p. 403) the Elsinore metamorphic series. They occur as disconnected strips, elongated parallel to the strike of the beds. These remnants of what may have been formerly a continuous blanket of sediments range in length from a few hundred feet to several miles, and in width from a few tens of feet to about a mile. Within the Val Verde district, 12 such bodies of schist were mapped (Fig. 2).

Quartz-biotite schist is the dominant metamorphic rock and this grades into quartzite in a few places. The schist contains variable proportions of quartz, biotite, muscovite, hornblende, oligoclase, and orthoclase. Near 
acidic igneous rocks, injection or replacement gneiss has been formed with very irregular and indefinite contacts. Small bodies of granitized schist occur in the intrusive, and apophyses of igneous rock protrude through the schist. Foliation in the schist is parallel to the bedding.

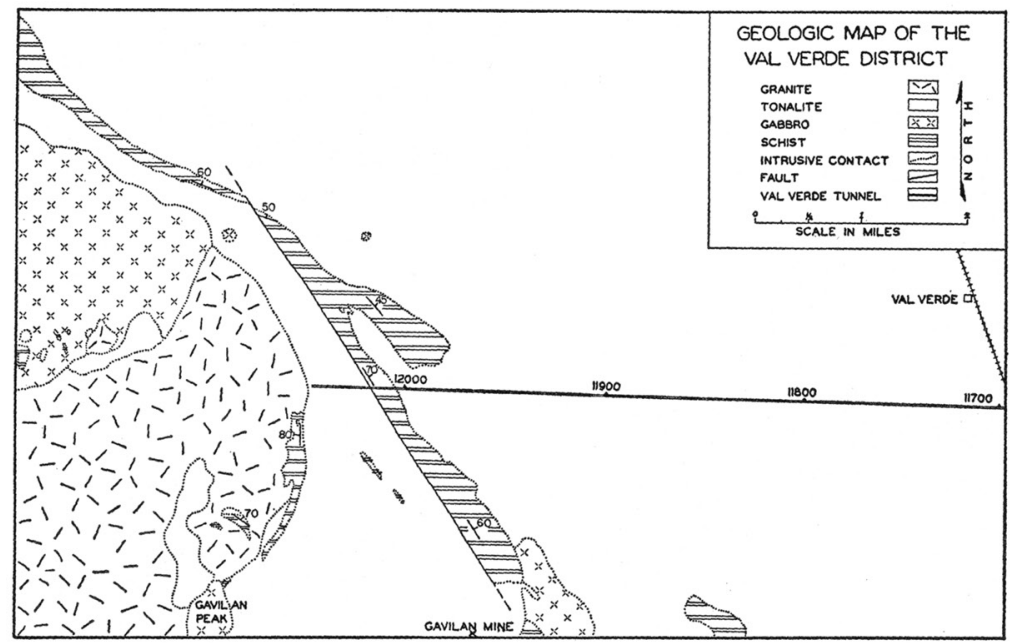

FIGURE 2.-Geologic map of the Val Verde district

Figures along line of tunnel refer to distance in hundreds of feet from Parker Dam on the Colorado River.

Based on lithologic correlation with the Triassic metamorphic series in the Santa Ana Mountains, 12 miles to the southwest, the age of the schist is believed to be Triassic.

\section{IGNEOUS ROCKS}

General statement.-In probable order of decreasing age the igneous rocks of the Val Verde district are gabbro, tonalite, granite, and basic and acidic dikes. These form a series intruded apparently during the same period of igneous activity.

Gabbro.-The igneous rock thought to be the oldest in the district is the Gavilan Peak gabbro, which crops out at five localities in the western part of the district. The rock is dark, massive, medium- to coarsegrained, and hypidiomorphic. Bytownite $\left(\mathrm{An}_{85-90}\right)$ constitutes 60 to 70 per cent of the rock, and augite, olivine, and hornblende, in variable proportions, make up the other 30 to 40 per cent. At some places near the contact with tonalite, olivine and augite are absent, their place being taken by hornblende and biotite which commonly enclose andesine poi- 
kilitically (Pl. 1, fig. 1). The gabbro clearly intrudes the schist in the extreme western part of the district.

Tonalite.--The Val Verde tonalite, named by Ransome (1932), crops out over the entire eastern and central parts of the district, and occurs in the western part as isolated masses. On the basis of mapping by Dudley (1935), ${ }^{1}$ tonalite is believed to underlie an area of at least 150 square miles on the Perris Block.

The tonalite is light-gray, medium-grained, and possesses a gneissoid structure which parallels in general the strike and dip of the schist. From the eastern end of the tunnel to the tonalite-schist contact, 5 miles to the west, it varies only slightly in composition and general appearance. The percentages of the minerals for an average sample of the rock are: andesine 57, quartz 26, biotite 12, hornblende 4, and orthoclase 1 per cent. Andesine and hornblende are subhedral, and biotite and quartz are anhedral. Most of the orthoclase is anhedral and closely associated with biotite. Commonly, however, small amounts of orthoclase occur as tiny rectangular blocks in the andesine aligned parallel to the cleavage directions of the host mineral. Biotite, quartz, and orthoclase are later than andesine and hornblende (Pl. 1, fig. 2). The accessory minerals, occurring in small amounts, are apatite, zircon, sphene, magnetite, pyrite, and rarely tourmaline. Wilson (1937, p. 124) reported also monazite and anatase. The average diameter of the grains is $1.0 \mathrm{~mm}$., but a small percentage of the grains attain a maximum length of 3 to $5 \mathrm{~mm}$.

The texture of the tonalite is dominantly igneous but the rock possesses two characteristics which indicate some deformation and recrystallization: (1) Contacts between mineral grains are commonly sutured, and, although cataclastic structures are not generally evident, andesine grains are locally bent or broken (Pl. 2, fig. 1). (2) The quartz not only commonly shows undulatory extinction but some grains are divided into several segments having slightly different extinction directions and sharp boundaries (Pl. 2, fig. 2). The "segmented" quartz grains may represent quartz which has not entirely recrystallized following deformation.

The tonalite intrudes the schist, but the contacts are gradational and irregular, suggesting that assimilation may have been important during emplacement of the tonalite. The tonalite grades into the schist through first a tonalitic gneiss containing bands high in quartz and biotite, and second a gneiss resembling the quartz-biotite schist but containing bands high in feldspar. In this transitional zone the foliation of the tonalite is parallel to the bedding planes of the schist.

\footnotetext{
1 The Val Verde tonalite is the same as the Perris quartz diorite of Dudley.
} 


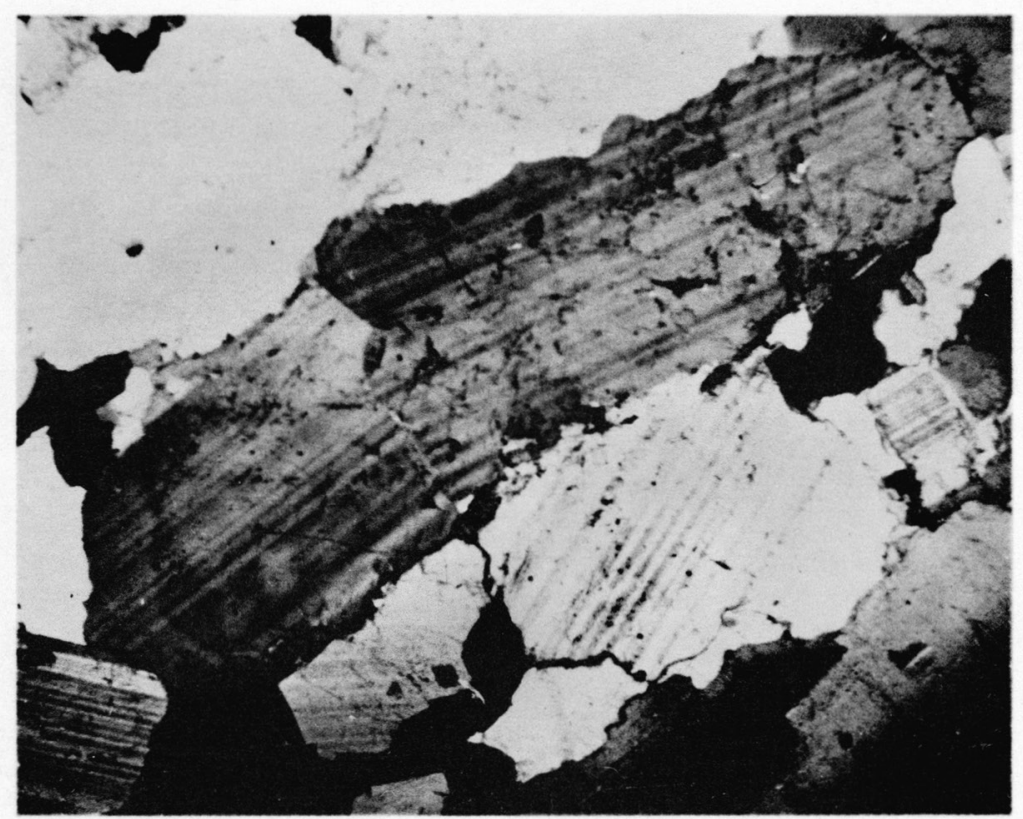

Figure 1. Diskupted Andesine Crystal Crossed nicols (x 50).

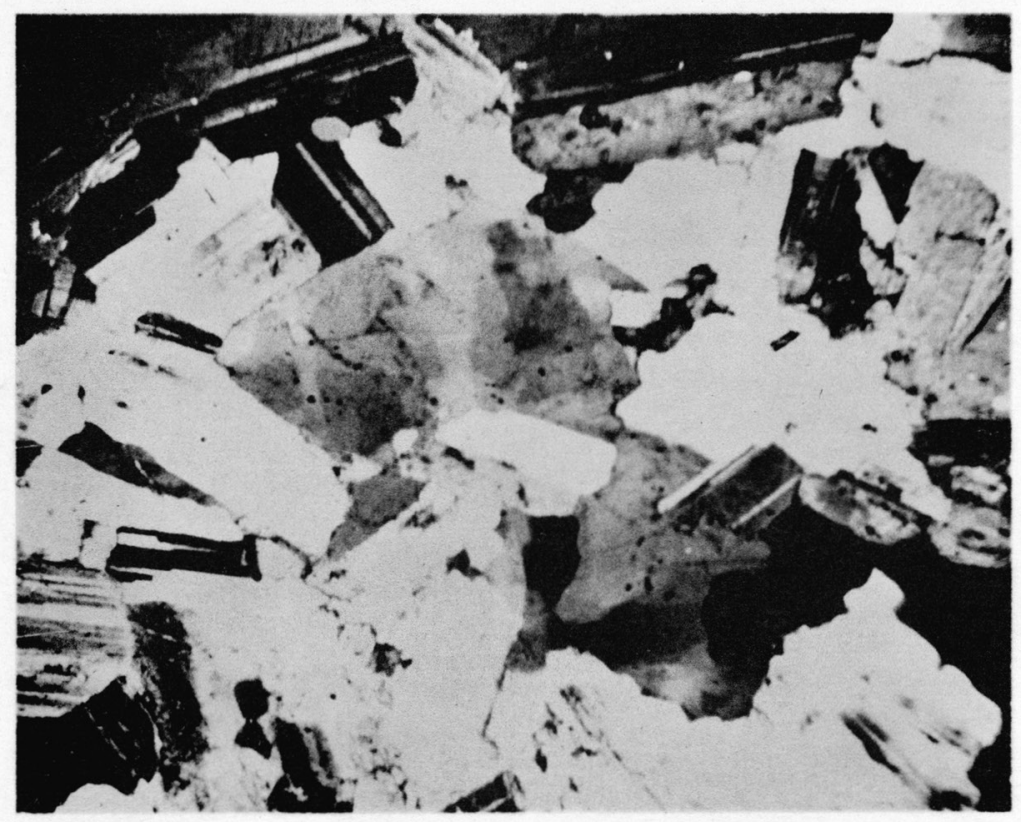

Figure 2. Two Anhedral Granulated Quartz Grains Crossed nicols (x 35).

PHOTOMICROGRAPHS OF TONALITE 


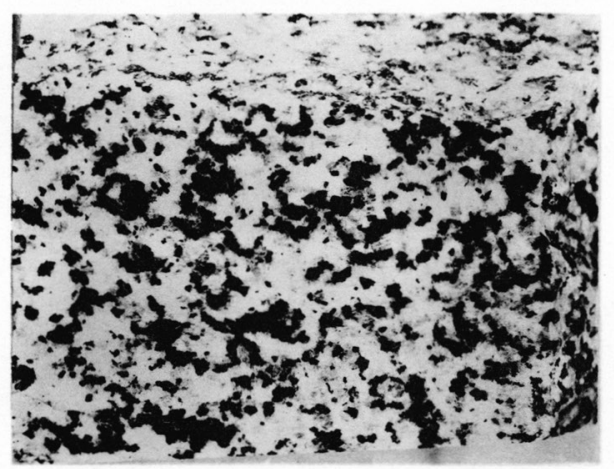

Figure 1. Tonalite

$a c$ face. $a$ is horizontal, $c$ is vertical.

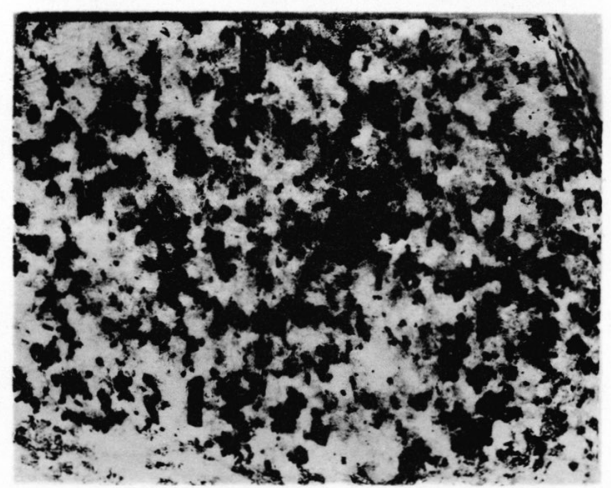

Figure 2. Tonalite

$a b$ face. $a$ is horizontal, $b$ is vertical.

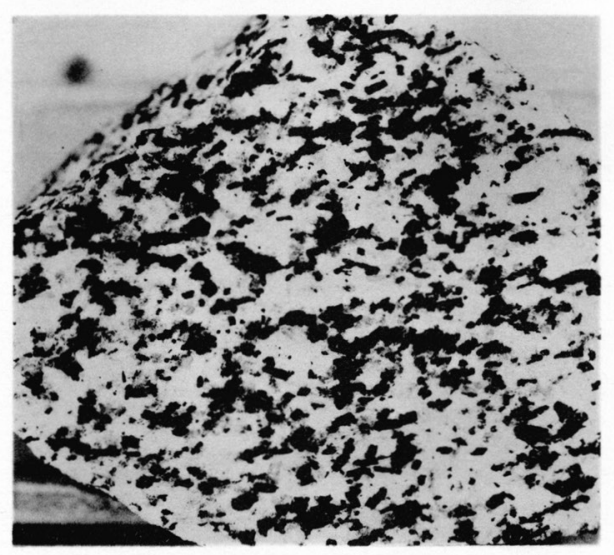

Figure 3. Tonalite

$b c$ face. $b$ is horizontal, $c$ is vertical.

HAND SPECIMEN ORIENTED WITH RESPECT TO AXES OF REFERENCE Natural Size 
In the few places in which contact relations with gabbro are unequivocal the tonalite intrudes the gabbro, but in some places the boundaries appear gradational and age relations are not clear.

Inclusions in tonalite.-Discoidal masses of dark, fine-grained rock, ranging in maximum dimensions from less than an inch up to several tens of feet, occur as inclusions in the tonalite, and are arranged parallel to the foliation. These dark bodies are absent over some areas as large as a few hundred feet in diameter, and in others constitute 60 per cent of the rock. Elongation of the inclusions within the plane of gneissosity is not evident, and the foliation of the tonalite is not noticeably curved around the inclusions but rather appears to pass through them. Boundaries between most of the inclusions and the tonalite appear sharp to the unaided eye and in thin section can be seen to be gradational over a distance of not more than 2 or 3 millimeters, but a small percentage of the inclusions blend into the tonalite to the extent that no definite boundary is evident. The inclusions are much more variable than the host rock, but as an average contain about 50 per cent plagioclase, ranging in composition from bytownite to oligoclase, 10 per cent quartz, and 40 per cent hornblende and biotite, hornblende commonly being more abundant than biotite. Orthoclase is present in only one inclusion examined. Apatite, zircon, magnetite, and rarely sphene are the accessory minerals. The average diameter of the grains is $0.25 \mathrm{~mm}$., the size varying with the inclusion; but within a single inclusion the grain size is uniform. Grains are anhedral, contacts are notably sutured, and an order of crystallization is not apparent.

Granite.-Granite ${ }^{2}$ which crops out in the western part of the district and also occurs as dikes in the tonalite, is light-brown, medium-grained, and possesses a gneissoid structure parallel to that in the tonalite. Dark, fine-grained inclusions are sporadically present, but are not generally as abundant as they are in the tonalite.

Determination of the composition of the granite is based on four specimens believed in the field to be typical of the particular locality from which they were taken. Quartz composes about 30 per cent of the rock, biotite about 5 per cent, oligoclase 5 to 20 per cent, and orthoclase and microcline 45 to 60 per cent.

At some localities the granite clearly intrudes the tonalite, but along the main tonalite-granite contact no definite boundary between the two rock types could be found.

2 This granite is the eastern part of the intrusive named by Dudley (1935) the Cajalco quartz monzonite. 
Dikes.-Numerous granite, aplite, and pegmatite dikes, and a few quartz monzonite, diorite, and quartz diorite dikes intrude the other rock types in the district. Most of these late intrusives are planar bodies accordant with the structure of the country rock. Some are plug-like masses roughly circular in plan.

Age and correlation.-All the igneous rocks intrude the Triassic metamorphic series and are earlier than the Eocene Alberhill clays (Dudley, 1935, p. 505). In the Santa Ana Mountains, which border the Perris Block on the west, igneous rocks similar to those in the Val Verde district are overlain unconformably by the Trabuco formation which is either late Lower, or early Upper, Cretaceous (Popenoe, W. P., personal communication, 1937). It seems probable, therefore, that the igneous rocks were emplaced during the Jurassic period, or at least during the Mesozoic era, and are comparable in age to intrusives in the Sierra Nevada.

\section{STRUCTURAL GEOLOGY}

The position of the Val Verde district with respect to the main structural features of southern California is shown in Figure 1. The district is located between two major strike-slip faults, the San Jacinto on the east and the Elsinore on the west. These faults strike approximately N. $30^{\circ} \mathrm{W}$. and are vertical.

The structural trend within the Val Verde district is outlined by the narrow body of schist which crosses it from northwest to southeast. In the southern and central parts of the district the schist strikes N. $20^{\circ}$ to $30^{\circ} \mathrm{W}$. and dips steeply to the northeast. In the northern part of the district the schist swings westward, assuming a N. $60^{\circ}$ to $65^{\circ} \mathrm{W}$. strike and a slightly lower angle of dip. The foliation in the tonalite and granite, the inclusions, and most of the dikes follow this same trend. The foliation in the tonalite, however, decreases in dip eastward from the contact with the schist and is essentially horizontal at the eastern end of the tunnel.

Numerous faults and joints cutting the tonalite occur in the tunnel. Most of these structures strike northwest and dip steeply. No constant relation between faults, joints, flow structure, and dikes could be established. If the fractures connected with the intrusion of the tonalite are present, they cannot be differentiated from later structures. The largest fault is one located at the western contact of the schist and tonalite. It is represented by a vertical zone of crushed and sheared rock and gouge 10 to 15 feet wide, striking N. $30^{\circ}$ W. This fault (Fig. 2) has been traced on the surface for a distance of 4 miles, and the body of schist which it transgresses is offset approximately 500 feet, the west side having been shifted northwestward with respect to the east side. 
Drag folds with an amplitude of a few inches occur sparingly in the schist. The axes of the folds are approximately horizontal. Vertical joints commonly cross the folds at right angles to the strike of the axes. Near the contact with the tonalite another type of fold occurs in the schist, the beds being commonly contorted and crinkled about an axis which parallels the dip of the schist.

\section{MICROMETRIC AND RADIOACTIVITY MEASUREMENTS}

GENERAL STATEMENT

An important part of the investigation was concerned with variation in mineralogic composition and radioactivity of the tonalite. The problem was of particular interest because of the unique opportunity to study fresh samples of a rock collected at regular intervals over a distance of 5 miles across a single intrusive. Study of the heavy minerals was made by $R$. W. Wilson of the geology department, and of the radioactivity by R. A. Clarke and F. H. Wright of the physics department of the California Institute of Technology.

The writer's contribution to the problem is divided into four sections: (1) examination of errors involved in sampling the rock; (2) determination of variation in mineralogic composition of the tonalite along the line of the tunnel; (3) correlation of these data with those obtained from heavy mineral and radioactivity studies; and (4) application of micrometric and radioactivity data to the problem of origin of the inclusions.

ERRORS IN SAMPLING VAL VERDE TONALITE

In a recent paper by Larsen and Miller (1935) errors involved in determining the mineralogic composition of a rock by a Rosiwal analysis of a thin section are discussed. Before examining the Val Verde tonalite for mineralogic variation, an attempt to evaluate sampling error was made by subjecting the rock to the various tests used by Larsen and Miller. Rosiwal analyses were made by using a Leitz six-spindle integrating stage, spacing the traverses at intervals of 1 millimeter. Aside from its bearing on the specific problem, the following description is presented in some detail because of the interest which it may hold for the student of similar problems.

In order to test the accuracy of the measuring method, two measurements were made on each of two thin sections of tonalite. On each thin section one measurement was made parallel to the trace of the plane of foliation, and the other measurement was made normal to this direction. The deviation from the average value of the two measurements 
on a thin section was not greater than one per cent ${ }^{3}$ for any constituent. ${ }^{4}$

To gain some idea as to the size of thin section necessary to give accurate results two tests were used. First, ten large thin sections were divided in half and the upper and lower halves measured separately, a method used by Larsen and Miller (1935, p. 264). The length of traverse

TABLE 1.-Measurements on separate halves of two thin sections

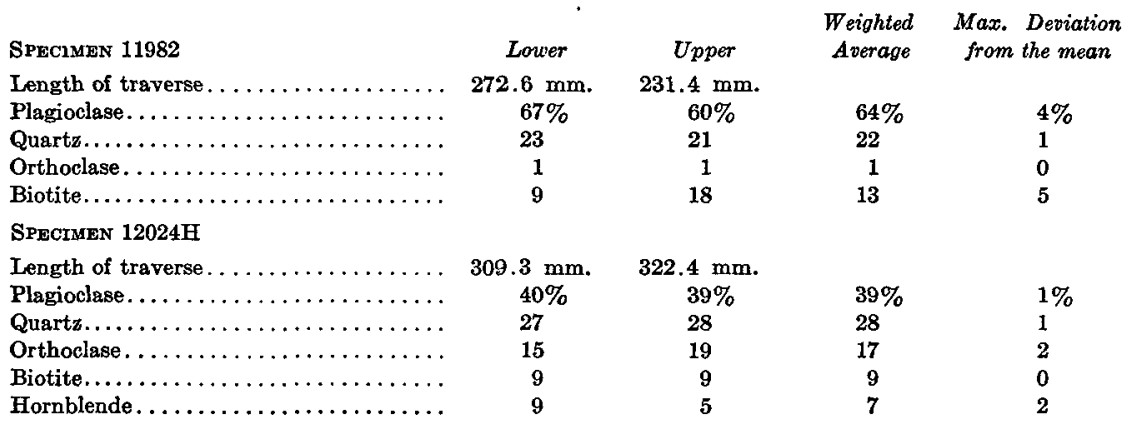

across half a section averaged about $250 \mathrm{~mm}$., or in other words, the area was about 250 sq. $\mathrm{mm}$. The maximum deviation of any single constituent in one half from the average of the two halves was 5 per cent. The average deviation from the mean in per cent for the ten sections was, for plagioclase 2.1, for quartz 1.1, for orthoclase 1.4, for biotite 1.7, and for hornblende 0.8. In Table 1 are given the values for two of the thin sections. The first is the section possessing the least correspondence between the two halves, and the other is one showing about average correspondence.

Inasmuch as sections averaging $250 \mathrm{sq} . \mathrm{mm}$. introduce a possible error of 4 to 5 per cent for an individual constituent, sections smaller than this were not considered reliable as samples of the rock.

Second, two thin sections larger than $300 \mathrm{sq}$. mm. were made from each of three hand specimens. The chips from which the sections were made were taken approximately two inches apart. Table 2 lists the results obtained from measurements of these thin sections.

The correlation shown in Table 2 is interesting in that two large thin sections of the same hand specimen agree more closely than two halves of the same large section (Table 1). The maximum deviation in a single thin section from the mean of the two sections of the same specimen

\footnotetext{
${ }^{3}$ In this and succeeding discussion, per cent are used as units when referring to deviation from a mean value. Thus, a deviation of 1 per cent from a mean value of 14 per cent indicates a possible fluctuation from a maximum of 15 to a minimum of 13 per cent.

4 The data on these measurements are not given here inasmuch as they serve only as corroboration of other published investigations on the accuracy of the Rosiwal method. The data are contained, however, in Ph.D. Thesis of E. F. Osborn, California Institute of Technology, 1937.
} 
is one per cent for plagioclase, quartz, orthoclase, and biotite, and 1.5 per cent for hornblende. This error is about the same as that of the measuring method itself; it is therefore concluded that one thin section larger than 300 sq. $\mathrm{mm}$. is sufficient as a sample of a hand specimen

TABLE 2.-Measurements of two thin sections from each of three hand specimens

\begin{tabular}{|c|c|c|c|c|c|c|}
\hline Specimen & $I a$ & $I b$ & $I I a$ & $I I b$ & $I I I a$ & $I I I b$ \\
\hline Length of traverse. . . . . . . . . & $412.1 \mathrm{~mm}$. & 504.0 & 317.8 & 611.3 & 562.5 & 598.7 \\
\hline Plagioclase $\ldots \ldots \ldots \ldots \ldots \ldots$ & $63 \%$ & $63 \%$ & $52 \%$ & $51 \%$ & $42 \%$ & $44 \%$ \\
\hline 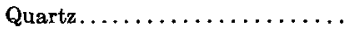 & 23 & 22 & 30 & 29 & 27 & 28 \\
\hline Orthoclase............. & 1 & 1 & 1 & 1 & 14 & 14 \\
\hline Biotite . . . . . . . $\ldots \ldots \ldots$ & 13 & 14 & 13 & 12 & 9 & 8 \\
\hline Hornblende. . . . . . . . . . . & 0 & 0 & 4 & 7 & 8 & 6 \\
\hline
\end{tabular}

TABLE 3.-Composition of eight samples of tonalite taken from area six feet in diameter

\begin{tabular}{|c|c|c|c|c|c|c|}
\hline \multicolumn{7}{|c|}{ CoMposirion } \\
\hline Sample No. & $\begin{array}{c}\text { Length of } \\
\text { traverse }\end{array}$ & Plagioclase & Quartz & Orthoclase & Biotite & Hornblende \\
\hline$A, \ldots \ldots \ldots \ldots \ldots$ & $447.5 \mathrm{~mm}$. & $42 \%$ & $27 \%$ & $15 \%$ & $12 \%$ & $4 \%$ \\
\hline $\mathbf{B} \ldots \ldots \ldots \ldots \ldots$ & 519.6 & 44 & 28 & 13 & 9 & 6 \\
\hline$C \ldots \ldots \ldots \ldots \ldots$ & 562.5 & 42 & 27 & 14 & 9 & 8 \\
\hline $\mathbf{D} \ldots \ldots \ldots \ldots \ldots$ & 460.3 & 44 & 29 & 11 & 11 & 5 \\
\hline $\mathbf{E}, \ldots \ldots \ldots \ldots \ldots \ldots$ & 354.5 & 34 & 25 & 27 & 8 & 6 \\
\hline $\mathbf{F} \ldots \ldots \ldots \ldots \ldots$ & 598.7 & 44 & 28 & 14 & 8 & 6 \\
\hline$G \ldots \ldots \ldots \ldots \ldots$ & 503.2 & 43 & 29 & 17 & 8 & 3 \\
\hline $\mathbf{H} \ldots \ldots \ldots \ldots \ldots$ & 631.7 & 40 & 27 & 17 & 9 & 7 \\
\hline Mean Value......... & $\ldots \ldots$ & 41.6 & 27.5 & 16.0 & 9.2 & 5.6 \\
\hline
\end{tabular}

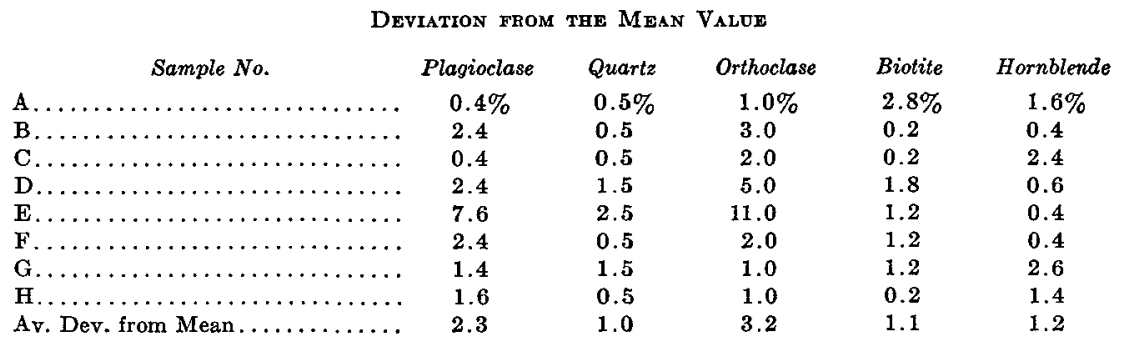

of the tonalite. Most of the thin sections used in determining variation in composition of the tonalite were larger than $300 \mathrm{sq} . \mathrm{mm}$. and none was smaller than 250 sq. $\mathrm{mm}$.

The final test made was on the accuracy of a hand specimen as a sample of a larger body of rock. At station 12024 in the Val Verde tunnel (Fig. 2) eight specimens of what appeared to be typical tonalite were taken from an area six feet in diameter. Later study revealed that the rock was not tonalite, but that it varied in composition from granodiorite to quartz monzonite. Table 3 lists the composition of the samples as determined from one large thin section of each and gives also the 


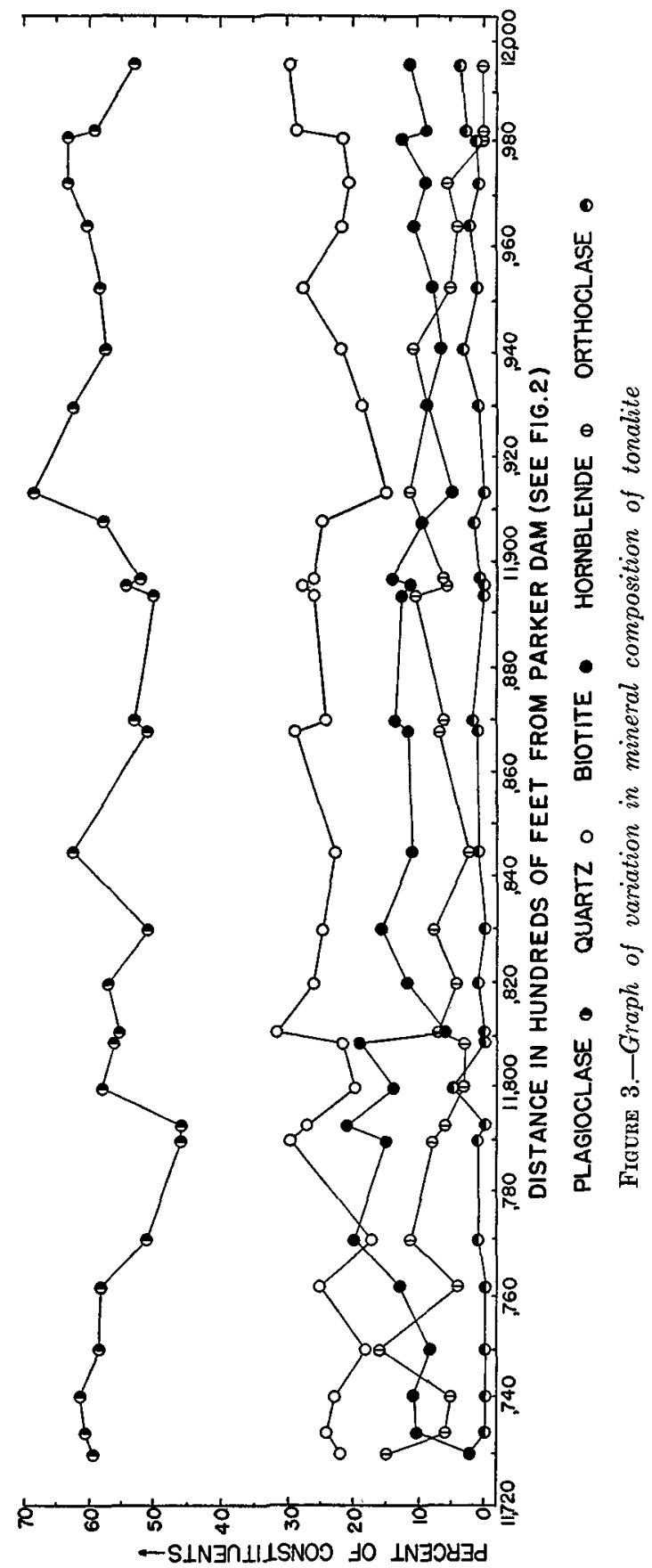


average deviation from the mean for each constituent. The samples are very close in composition except for number " $E$ ", which has a rather different plagioclase-orthoclase ratio from the others. The mineral with the largest average deviation from the mean is orthoclase with a value of 3.2 per cent. If the tonalite along the tunnel is as uniform as the rock at this station, then variations in composition from point to point greater than about 3 per cent for a single constituent are probably outside the limits of error of the sampling method.

\section{VARIATION IN MINERALOGIC COMPOSITION OF TONALITE}

Twenty-nine sections have been measured to find the variation in composition of the tonalite along the line of the tunnel, and the results are shown in Figure 3. No mineral tends to increase or decrease regularly from east to west through the tunnel, although the tonalite near the west end contains in general slightly more orthoclase.

The variation in composition of the plagioclase, however, is significant. As shown on the upper graph of Figure 4, the plagioclase becomes more sodic toward the western end of the tunnel. Thus, the generalization may be made that the tonalite is more acidic toward the western end of the tunnel or toward the border of the intrusive. Wilson (1937, p. 129) came to the same conclusion from a study of the heavy accessory minerals. He found that toward the contact zircon increased in amount, apatite decreased, and there was an introduction of tourmaline and anatase.

The more acidic border of the tonalite is believed to be due to assimilation of quartz-biotite schist. Incorporation of this material into the tonalite magma would tend to make it more acidic, and contact relations indicate that assimilation may have been important. Radioactivity measurements, which are discussed in the next section, show that radioactivity of the tonalite increases toward the contact with the schist. This is suggestive of assimilation, since the schist as observed away from the contact averages higher in radioactivity than the tonalite.

\section{CORRELATION OF MINERALOGIC DATA WITH RADIOACTIVITY DETERMINATIONS}

Radioactivity determinations. ${ }^{5}$ - Radioactivity measurements ${ }^{6}$ were made on the tonalite from 35 different stations along the tunnel and on specimens of granodiorite, granite, schist, gabbro, inclusions, and dikes.

Results of measurements of the tonalite are plotted on the lower graph in Figure 4. Although the points are rather scattered, a curve has been drawn which correlates very well with that giving the albite content of

\footnotetext{
In the following discussion the values listed for radioactivity are proportional to the number of alpha particles emitted per unit time per unit weight of sample. As far as is now known, the only elements involved are members of radium, thorium, and actinium series.

A paper by Clarke and Wright is in preparation giving a description of apparatus and method and giving more detailed results than those listed herein.
} 
the plagioclase along the tunnel. There may be some doubt as to the existence of the wave in the curves between stations 11760 and 11850 , but the rise in both curves toward the west, or toward the contact with the schist, is real.

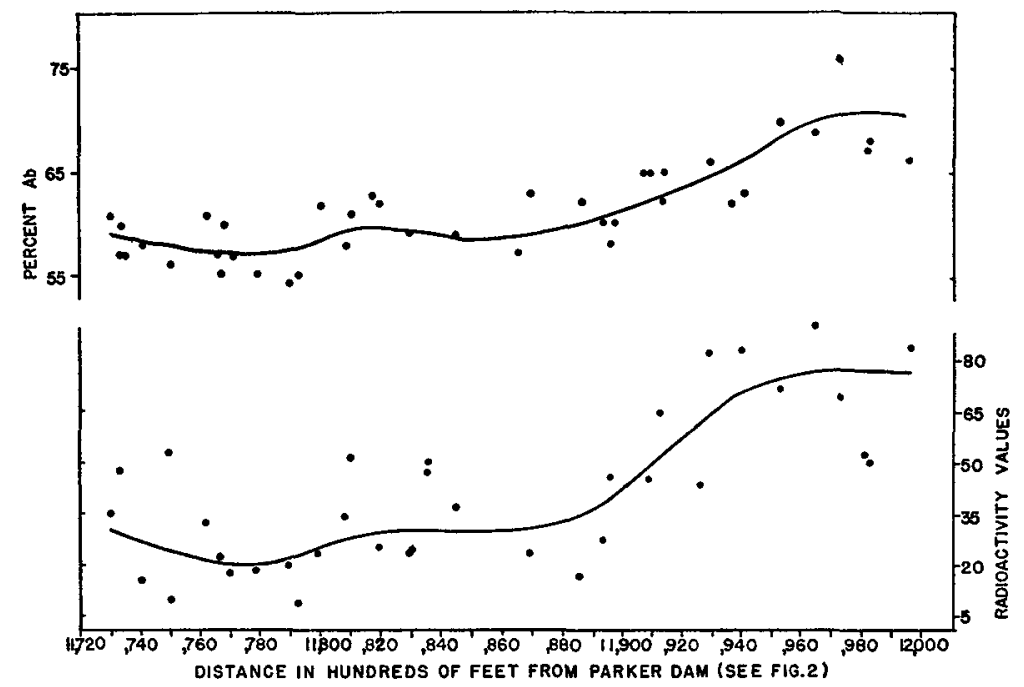

FrguRE 4.-Graphs of albite content of plagioclase and radioactivity of tonalite

A summary of the data concerning correlation of radioactivity with rock type is given in Table 4 . These data show a direct relation between radioactivity and acidity of the rock.

Earlier studies of radioactivity of rocks.--Lord Rayleigh (Strutt, 1905) was the first to point out the direct relation between radioactivity and acidity of rocks. The data presented herein furnish additional proof of the correctness of the generalization. Since 1905 a series of investigations has dealt with the relation of radioactivity and chemical and mineralogic constitution of rocks. As examples, Waters (1909 and 1910) found that in the Cornish granite the radium was concentrated in anatase or rutile, in the Dalbeattie granite in allanite, and in the Mourne granite chiefly in zircon and some titaniferous mineral. Fletcher (1911), in studying the Leinster granite, found that the radioactivity of the rock was due mostly to micas containing inclusions of zircon. Hirschi (1927) in investigating the intrusive rocks of the Aar massif found a direct relation between the potassium content of the rocks and the radioactive elements of the uranium-thorium series. Piggot and Merwin (1932) examined two granites with a high content of radioactive substances, one 
from Stone Mountain, Georgia, and the other from North Jay, Maine. As a result of their work, they concluded that in mica-bearing granites the radium is associated more with the micas than with other constituents of the rock. Evans and Williams (1935) concluded from a study of the

TABLE 4.-Correlation of radioactivity and rock type

Number of Speci
mens Examined
3
1
10
2
35
6
1
8
3
1

\begin{tabular}{|c|c|}
\hline Rock Type & $\begin{array}{l}\text { Av. Value of } \\
\text { Radioactivity }\end{array}$ \\
\hline 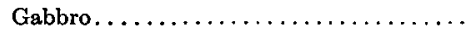 & 0 \\
\hline Diorite dike. . . . . . . $\ldots \ldots \ldots \ldots \ldots$ & 11 \\
\hline "Gabbro" inclusions............... & 20 \\
\hline “Schist" inclusions. . . . . . . . . . . . & 64 \\
\hline Tonalite $\ldots \ldots \ldots \ldots \ldots \ldots \ldots$ & 42 \\
\hline 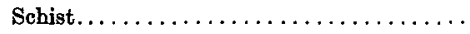 & 46 \\
\hline Aplite..................... & 52 \\
\hline Granodiorite $\ldots \ldots \ldots \ldots \ldots \ldots \ldots$ & 95 \\
\hline 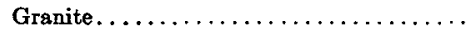 & 112 \\
\hline Pegmatite $\ldots \ldots \ldots \ldots \ldots \ldots \ldots \ldots \ldots$ & 220 \\
\hline
\end{tabular}

various types of lavas from Lassen Volcanic National Park that the amount of radium increases with the alkalies, especially potassium.

Source of radioactivity.-More work is to be done by Wright on the radioactivity of the individual minerals of the Val Verde tonalite, but tentative conclusions may be reached concerning the constituent of the rock with which the radioactive material is associated. An examination of Figures 3 and 4 is sufficient to show that the data so far obtained indicate no correlation between the radium-thorium-actinium content of the tonalite and the percentage of biotite, quartz, or hornblende. A slight correlation exists between the low points in the plagioclase (Fig. 3) and radioactivity (Fig. 4) curves, but this may be fortuitous. Also, orthoclase is slightly more abundant in the rock near the contact where the radioactivity is higher. It is possible that the radioactive substances are contained largely in zircon, ${ }^{7}$ which Wilson (1937) found to increase in amount toward the contact; in this case the amount of zircon in the tonalite may vary directly with the albite content of the plagioclase.

\section{ORIGIN OF DARK INCLUSIONS IN TONALITE}

The origin of the dark inclusions in the tonalite is an enigma not readily solved. If they are xenoliths, textural characteristics of the rocks from which they have been derived are lacking. The minerals, with exception of feldspar in some specimens, are the same as in the enclosing rock, but are in smaller grains, and the texture is granoblastic.

Twelve inclusions were examined for their mineralogic composition and radioactivity. The data obtained indicate that these are xenoliths of gabbro and schist. One specimen believed to have been originally

7 Monazite is not included in the discussion because of its extreme rarity (Wilson, 1937, p. 126). 
schist was taken from the center of a discoidal inclusion approximately 5 feet in diameter and one foot thick, located 400 yards from a schisttonalite contact. This specimen contains 6 per cent orthoclase, which is unusual for any dark-colored rock in the district except schist. The plagioclase is oligoclase, which is the variety most common in the schist, but more sodic than that in the enclosing rock. The value for the radioactivity is 81 , comparable to some of the higher values obtained from the schist. A second specimen believed to be a xenolith of schist was taken from an inclusion in the tonalite located near the western boundary of the district 20 feet from a schist-tonalite contact. A specimen of schist from the contact was taken for comparison. The inclusion is composed of 37 per cent oligoclase, 41 per cent quartz, 15 per cent biotite, and 7 per cent hornblende; the schist is composed of 38 per cent oligoclase, 25 per cent quartz, 17 per cent biotite, and 20 per cent hornblende. The value for the radioactivity of the inclusion is 46 and for the schist is 55 . The grain size is the same in both. In view of the variability of the schist, this is a very close correlation. The composition of the plagioclase crystals in both inclusions is sufficient to exclude the possibility that these inclusions are segregations from the tonalite or xenoliths of gabbro.

The other ten inclusions studied are thought to have been derived from the gabbro. In the first place, the composition of the plagioclase is suggestive. Two specimens were taken from near the center of inclusions having a maximum diameter greater than 6 feet and a thickness of one foot or more. They were located near station 11915 (Fig. 2) on the line of the tunnel in an area in which inclusions compose 50 to 60 per cent of the rock. In both specimens some of the plagioclase grains have cores of labradorite or bytownite $\left(\mathrm{An}_{60-80}\right)$. The only rock in the district containing plagioclase as calcic as this is gabbro. From similar evidence Hurlbut (1935) concluded that the inclusions in the Bonsall tonalite were xenoliths of gabbro. If the other eight inclusions are gabbro xenoliths, as is thought, then the plagioclase in them, which is the same as that in the tonalite, has been changed by reaction with the tonalite magma. In the second place, the average value for the radioactivity of the ten inclusions is 20. This value is much lower than the average for the schist and it is not probable that the radioactivity of the schist would be lowered that much by reaction with the tonalite because the tonalite is 42 . On the other hand, since the radioactivity of the gabbro is zero, reaction with the tonalite could change this value only by raising it. The ten inclusions are thus probably not xenoliths of schist. Some of them may have originated from other dark rocks not found on the surface, but inasmuch as gabbro is abundant in the district this is the most probable source. 
The fine-grained texture of the inclusions may be related to the breakdown of the gabbroic texture when reacted upon by acidic magma. Joplin (1935) studied the problem of hybridization of basic rocks by acidic magma and found that in the first stage a granoblastic texture is produced in the basic rock and granular masses of pyroxene and crisscross flakes of biotite may form. During and following this stage large, highly poikilitic crystals of hornblende and biotite are developed. As Joplin points out, movement in the magma would disrupt the poikilitic crystals, producing a fine-grained aggregate. This same general process was observed in the Gavilan Peak gabbro. The gabbro at Gavilan Peak is uncontaminated by the tonalite and it contains augite and olivine, the former partly altered to uralite. The gabbro in the western and northern parts of the district is closely associated with the tonalite, and thin sections of this gabbro contain only hornblende and biotite as the mafic constituents. Moreover, a thin section of a specimen of gabbro taken from the contact with tonalite contains unusually large, highly poikilitic crystals of hornblende enclosing fine-grained andesine ( $\mathrm{Pl}$. 1, fig. 1). If a block of this gabbro were surrounded by tonalite magma and carried along with it, the movement probably would be sufficient to disrupt the poikilitic crystals and produce a fine-grained rock.

\section{PETROFABRIC ANALYSES}

GENERAL STATEMENT

The schist and tonalite in the Val Verde district were subjected to petrofabric analyses as an additional means of obtaining information on the geologic history. Of particular interest was the problem of the origin of flow structure or foliation in the tonalite. At the contact with the schist, the flow structure parallels the schistosity, striking in general northwest and dipping steeply northeast. Eastward from the contact with the schist, however, the dip of the foliation lessens, becoming approximately horizontal at the eastern end of the tunnel. The lineation in the tonalite parallels the dip of the gneiss planes. Is this orientation of the minerals in the tonalite entirely a product of magmatic flow, or may it be partly or wholly a result of post-magmatic deformation?

The method used was that developed by Sander (1930) and Schmidt (1932) and followed by other workers in the field. All megastructures such as contacts, folds, faults, joints, foliation, orientation of inclusions, and lineation in the tonalite were mapped. From the oriented hand specimens oriented thin sections were made and were examined by means of a Leitz universal stage. The microscopic data were recorded on an equal-area projection. The projection of the points was made from the lower hemisphere on the equatorial plane of the sphere. 


\section{PETROFABRIC ANALYSIS OF SCHIST}

Axes of reference.-In accordance with the method of Sander, three axes of reference were set up for the oriented hand specimens of the schist. The $b$-axis is the tectonic axis, or that direction paralleling the axes of drag folds and small crinkles in the rock. The $a$-axis is that direction lying in the plane of schistosity or $a b$ plane, $90^{\circ}$ from $b$. The $c$-axis is normal to the $a b$ plane. In the field the $b$-axis is horizontal or dips at an angle less than $10^{\circ}$ to the northwest and is directed in a general north to northwest direction. The $a$-axis, therefore, approximately parallels the dip of the beds, which is in most places steep and to the east.

Fabric diagrams.--Oriented thin sections were made of four specimens of the schist, and optic axes of quartz grains and poles of basal planes of biotite were plotted. Figure 6 shows the results obtained on two of the specimens in thin sections cut normal to the $b$-axis. In the diagrams, $c$ and $b$ are horizontal and $a$ vertical, approximately as in the field. As shown in diagrams 1 and 3, the poles of the basal planes of biotite are concentrated about $c$. Inasmuch as the foliation, or $a b$ plane in the rock, is outlined in hand specimen by basal planes of biotite flakes, this orientation is exactly as would be expected. Biotite is not only concentrated at $c$, but also forms a nearly complete girdle about $b$. The optic axes of quartz grains, as shown in diagrams 2 and 4 also describe girdles about $b$. Several maxima are present in each diagram, with none appearing at $a$.

Joints and faults.- In general joints are not conspicuous in the schist, but in the body of schist half a mile south of the western end of the tunnel, well developed joints are common striking approximately at right angles to the strike of the schist and dipping vertically or steeply to the south. These are thus approximately parallel to the $a c$ plane of the schist fabric and undoubtedly represent the $a c$ joints of Sander.

The main fault in the district lies along the western border of the schist and parallels the schistosity.

Interpretation.--Inasmuch as the schistosity parallels the bedding, the orientation of the biotite flakes may be largely a residual structure. There may, therefore, have been no rotation of biotite grains into the $a b$ plane during deformation. Gliding within the biotite parallel to the cleavage may have occurred during movement of the rock, but this is not proven. The preferred orientation of quartz resulted from movement in the rock and might be explained by rotation of the grains in a plane normal to $b$, and by gliding along crystallographic planes. Inasmuch as only one $s$-surface is visible in hand specimens and only one is appar- 
ent in the biotite diagrams, the various quartz maxima are not readily explained as being due to the presence of two or more $s$-surfaces. By assuming gliding in quartz parallel to rhombohedrons during shearing parallel to the $a b$ plane, the occurrence of the quartz maxima may be

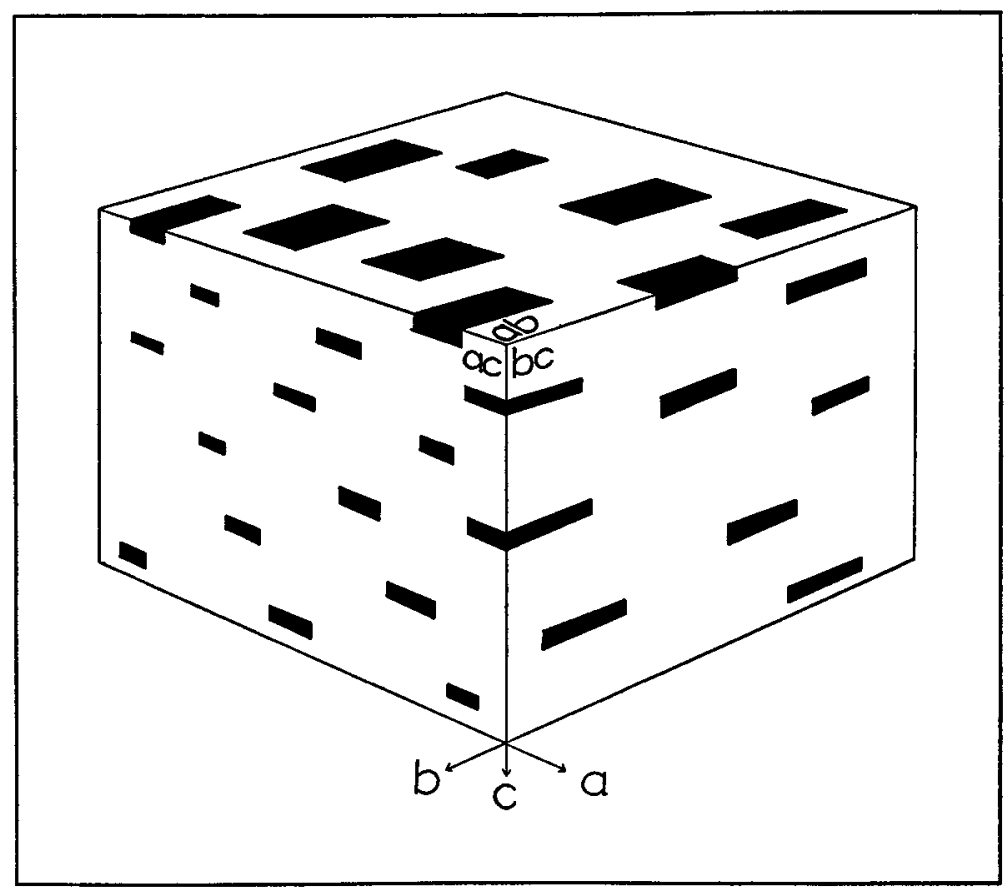

FIguRe 5.-Diagrams illustrating relation of axes of reference to dimensional orientation of grains in tonalite

explained reasonably well. But this assumption may not be valid. Recent experiments by Griggs and Bell (1938) indicate that a translation gliding mechanism is not present in quartz, and that during rock deformation quartz is fractured into needles whose elongation direction and bounding faces bear a relation to the crystal lattice. The needles are oriented in the $a$ fabric direction, with one of their bounding planes in the $a b$ plane. Later crystallization is assumed to obliterate traces of the needles. On the basis of this theory, only one shear plane in the rock is necessary.

\section{PETROFABRIC ANALYSIS OF TONALITE}

Axes of reference.-Axes of reference used for the tonalite have in general the same significance as for the schist despite the fact that one is an igneous and the other a metamorphic rock. As discussed by 
Sander and Felkel (1929), the same types of motion may occur in solidifying magmas as in tectonically deformed rocks, and the Val Verde tonalite is an igneous body for which this apparently holds true. The
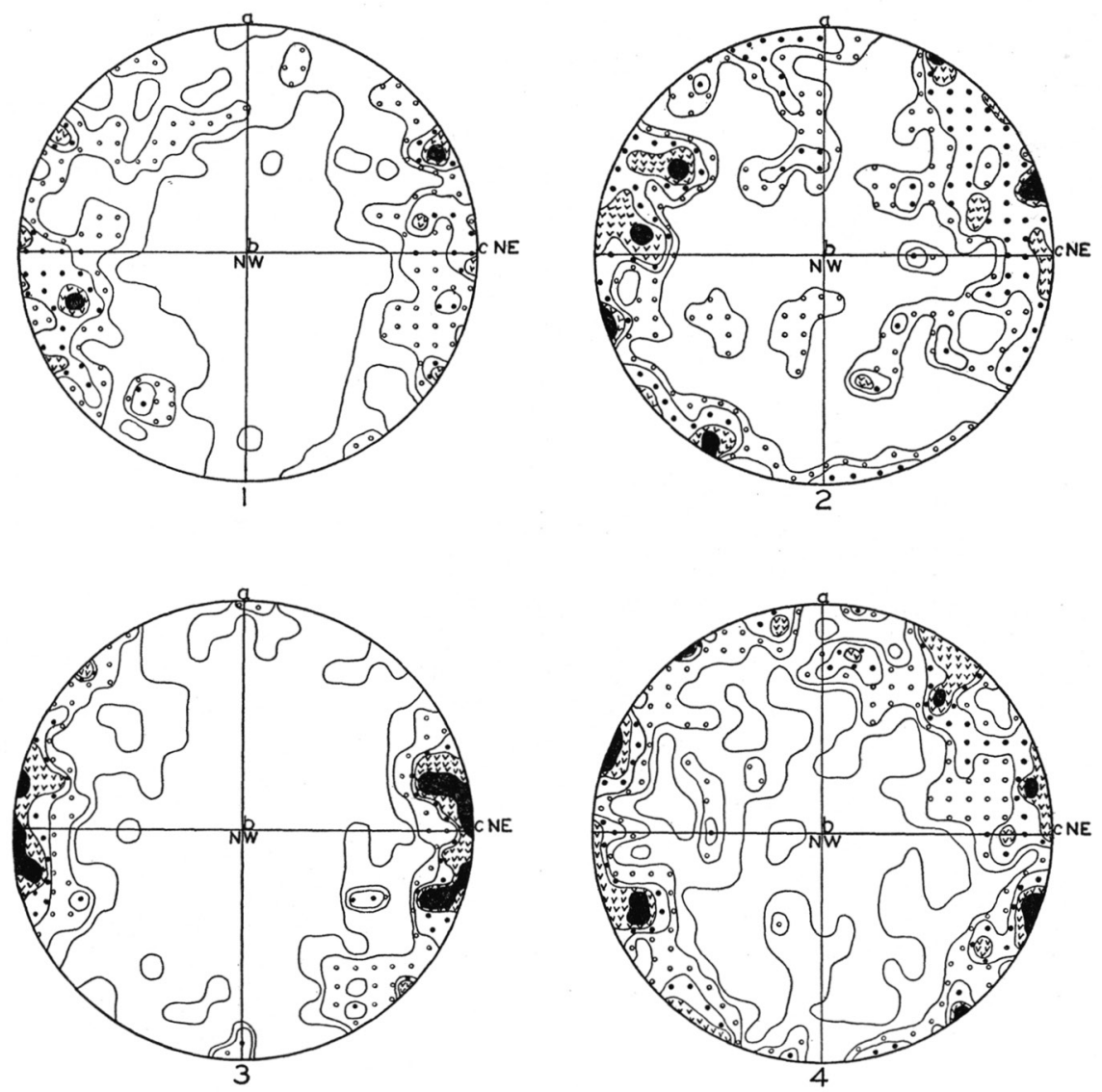

Frgure 6.-Fabric diagrams of schist

(1) Poles of basal planes of 308 biolite grains in sp. 12012 of quartz-biotite schist. Contours 5, 4, $3,2,1 \%$.

(2) Optic axes of 183 quartz grains in sp. 12012 of quartz-biotite schist. Contours 5, 4, 3, 2, $1 \%$.

(3) Poles of basal planes of 343 biotite grains in sp. 12011 of quartz-biotite schist. Contours 5, 4, $3,2,1 \%$.

(4) Optic axes of 319 quartz grains in sp. 12011 of quartz-biotite schist. Contours 5, 4, 3, 2, $1 \%$.

direction of movement in the tonalite, as shown by fabric analyses, lies in a plane normal to the lineation or direction of elongation in the rock. The lineation in the tonalite, therefore, is labeled $b$, signifying the axis of intersecting surfaces of movement or the axis about which grains 
have been rotated. In the field, $b$ parallels the dip of the foliation, which is steep at the schist contact, but gradually approaches the horizontal eastward. The $a$-axis lies in the plane of foliation and is normal to $b$;
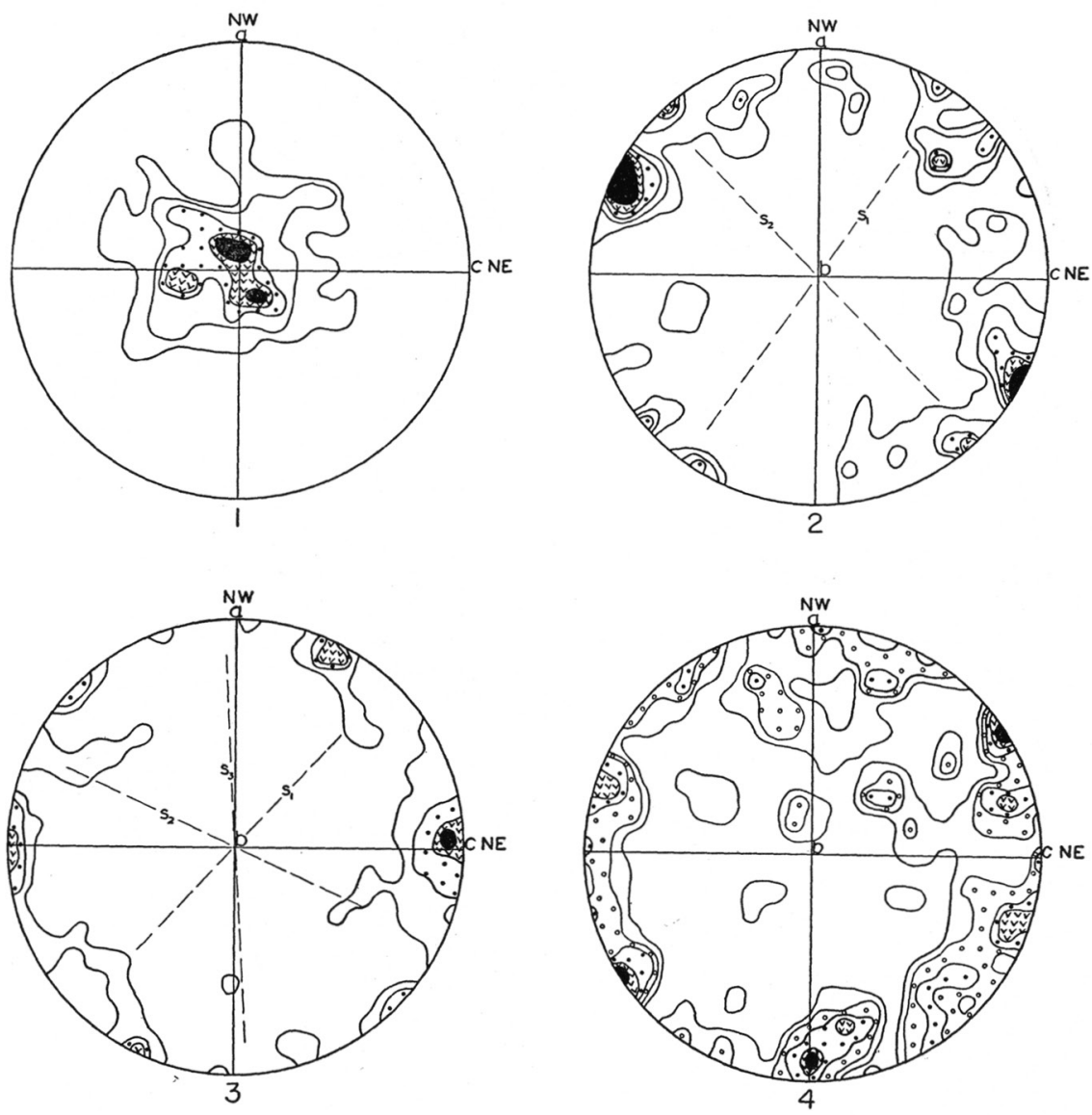

Figure 7.-Fabric diagrams of tonalite

(1) $a$-axes of 106 andesine grains in sp. 11868 of tonalite. Contours 10, 8, 6, 4, 2\%.

(2) Poles of 010 faces of 106 andesine grains in sp. 11868 of tonalite. Contours 5, 4, 3, 2, 1\%.

(3) Poles of basal planes of 88 biotite grains in sp. 11868 of tonalite. Contours 4, 3, 2, $1 \%$.

(4) Optic axes of 185 quartz grains in sp. 11868 of tonalite. Contours 5, 4, 3, 2, 1\%.

$a$ is thus approximately horizontal and trends northwest. The $c$-axis is normal to the $a b$ plane, or plane of foliation. Figure 5 and Plate 3 illustrate the scheme of orientation and the latter gives also an idea as to the degree to which the minerals are oriented in some of the tonalite specimens. 
Fabric diagrams.-Nine specimens of tonalite from the tunnel, distributed between stations 11734 and 12022, were examined. Typical diagrams obtained from three specimens of tonalite and one of an inclu-
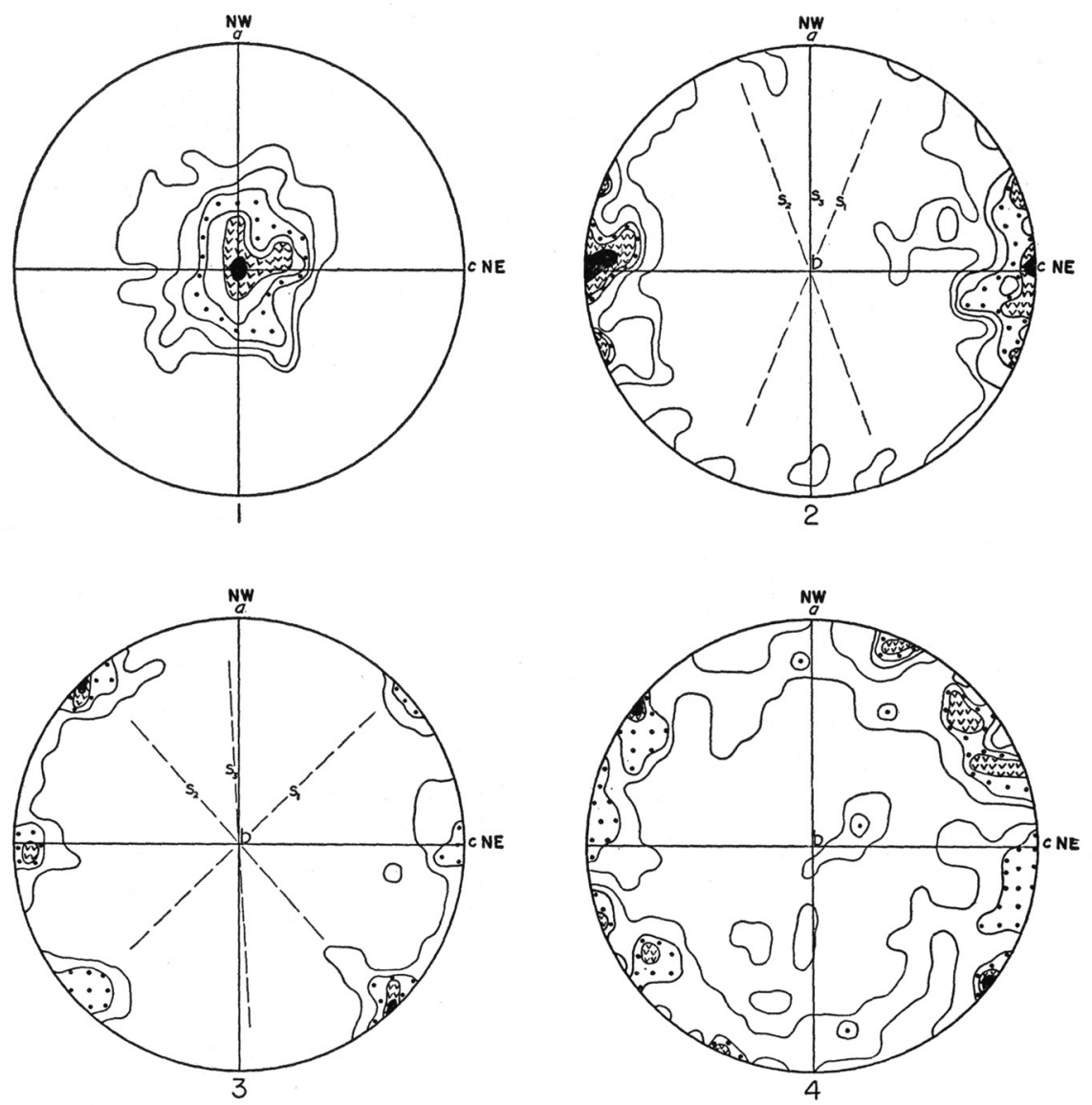

Figure 8.-Fabric diagrams of tonalite

(1) $a$-axes of 130 andesine grains in sp. 11870 of tonalite. Contours 12, 10, 8, 6, 4, 2\%.

(2) Poles of 010 faces of 130 andesine grains in sp. 11870 of tonalite. Contours 10, 8, 6, 4, 2\%.

(3) Poles of basal planes of 69 biotite grains in sp. 11870 of tonalite. Contours 4, 3, 2, $1 \%$.

(4) Optic axes of 163 quartz grains in sp. 11870 of tonalite. Contours 4, 3, 2, $1 \%$.

sion are shown in Figures 7, 8, and 9. Since lineation is not evident in the inclusions, the oriented section from the inclusion was cut normal to the linear direction in the adjoining tonalite. The positions of $s$-surfaces are labeled $\mathrm{S}_{1}, \mathrm{~S}_{2}$, and $\mathrm{S}_{3}$. These lines have been drawn parallel to concentrations of the (010) face of plagioclase and the basal plane of biotite. 
The lineation in the tonalite is determined by subparallel arrangement of prisms of hornblende and grains of plagioclase elongated parallel to the $a$ crystallographic axis. The degree to which lineation in the rock
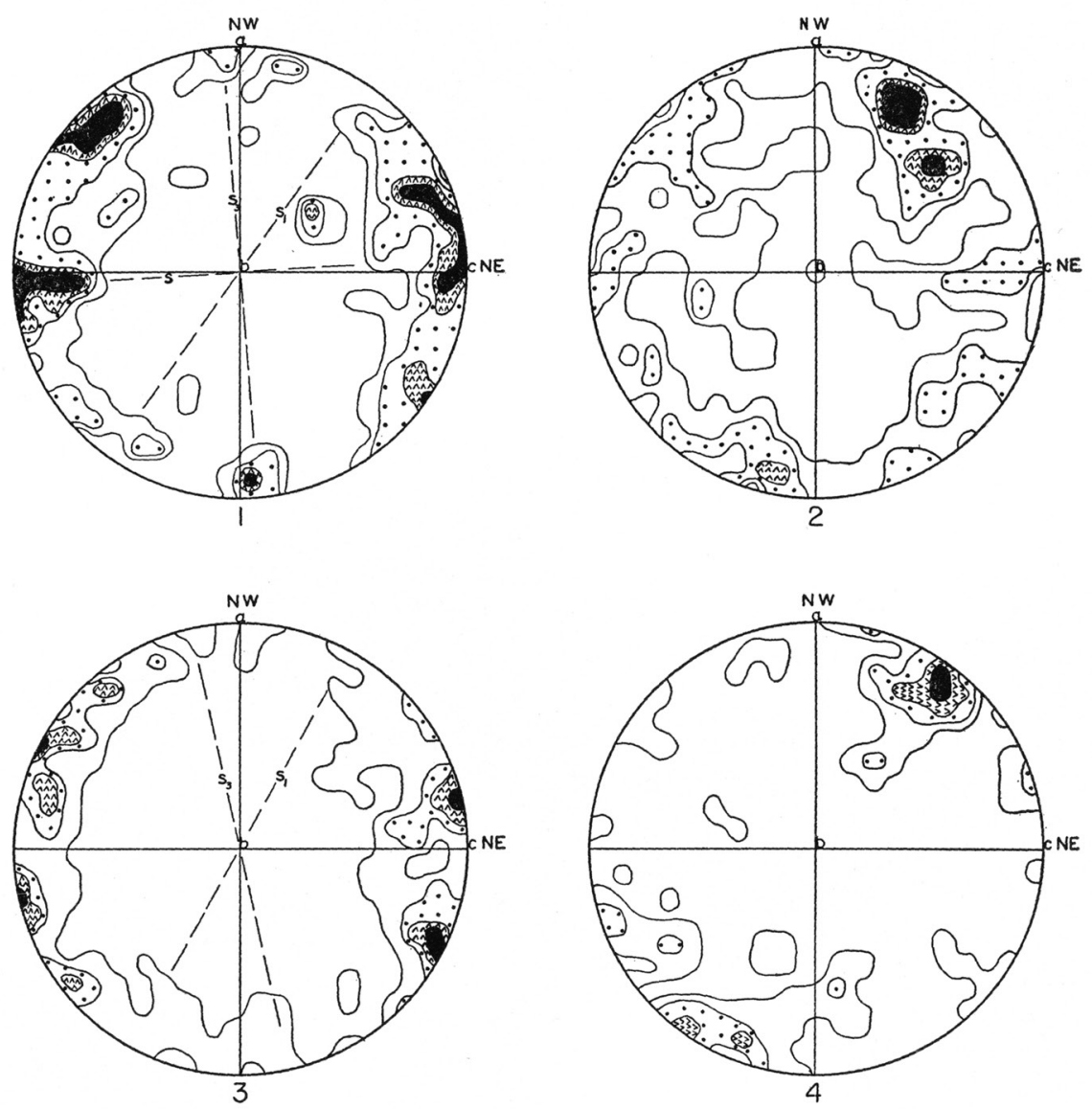

Figure 9.-Fabric diagrams of tonalite and an inclusion

(1) Poles of basal planes of 165 biotite grains in sp. 11982 of tonalite. Contours 4, 3, 2, $1 \%$.

(2) Optic axes of 260 quartz grains in sp. 11982 of tonalite. Contours 4, 3, 2, $1 \%$.

(3) Poles of basal planes of 143 biotite grains in sp. 11930 of an inclusion in tonalite. Contours 6, $4 \frac{1}{2}, 3,1 \frac{1}{2} \%$.

(4) Optic axes of 108 quartz grains in sp. 11930 of an inclusion in tonalite. Contours 8, 6, 4, 2\%.

is developed was determined by plotting the a-axis of the plagioclase in sections cut normal to the linear direction in the rock. Figure 7, (1) ; and Figure 8, (1) illustrate this.

Figure 7, (2) and Figure 8, (2) are plots of the poles of the (010) faces of plagioclase grains in the same two specimens. A discontinuous 
girdle is present in the plane normal to $b$, and in this girdle conspicuous concentrations of $(010)$ faces occur in two intersecting planes labeled $\mathrm{S}_{1}$ and $\mathrm{S}_{2}$, almost symmetrically arranged with respect to the $a b$ plane.

The quartz diagrams (Fig. 7, (4), Fig. 8, (4), and Fig. 9, (2)) possess a girdle of quartz optic axes in the plane normal to the $b$ tectonic axis, and within this girdle rather strong maxima occur, somewhat as in the schist diagrams. ${ }^{8}$ Figure 9, (4), a plot of the quartz grains in an inclusion in the tonalite, resembles Fig. 9, (2), but differs from it in having a less distinct and continuous girdle.

The biotite diagrams (Fig. 7, (3), Fig. 8, (3), and Fig. 9, (1) and (3)) of tonalite and an inclusion are from sections cut normal to $b$. Incomplete girdles occur in all diagrams, and besides a common concentration of poles of the basal planes at $c$, concentrations occur at other points in the $a b$ plane showing the presence of $s$-surfaces inclined to $a b$, similar to those appearing in the plagioclase diagrams.

Interpretation.-Fabric diagrams of quartz, biotite, and plagioclase in the tonalite are interpreted to mean that some movement in the tonalite was produced by rotation of mineral grains in a plane normal to the $b$-axis. The positions of the maxima of poles of the basal plane of biotite and (010) face of plagioclase indicate that three surfaces of movement, labeled $S_{1}, S_{2}$, and $S_{3}$ on the diagrams, were important during deformation. If gliding in quartz occurred, and if the gliding was parallel to prism faces, similar shearing directions are indicated by the quartz maxima.

The main object of this study has been to uncover evidence on the origin of the gneissoid structure in the tonalite and thus to obtain a more complete picture of the history of the intrusive. Three possibilities exist: (1) the structure was developed during the magmatic stage of the tonalite; (2) the structure was developed after complete solidification of the rock; and (3) the structure is a result of stresses operative on the rock both during and after solidification.

(1) In support of the hypothesis that the foliation is entirely a result of magmatic flow the following points may be listed ${ }^{9}$ : (a) The texture of the tonalite is essentially that of an igneous rock. Evidence of metamorphism is slight. (b) The attitude of the foliation and the direction of lineation are those normally to be expected were the foliation the result of primary flow (Balk, 1937). That is, at contacts with country rock the foliation is parallel to the contact and the linear direction is

\footnotetext{
8 Hurlbut (1935) and Pabst (1936) found no orientation of quartz in either the Bonsall tonalite, southern California, or in the intrusive rocks of the Sierra Nevada.

O Joint and fault patterns might be of use in distinguishing primary and secondary foliation, but the writer has not been able to use the fault and joint patterns mapped in the tunnel as evidence for any theory on the origin of the flow structure.
} 
parallel to the dip of the contact. (c) Inclusions are oriented parallel to the foliation, and it is most reasonable, especially in view of their large size and gradational borders in some instances, to assume that the inclusions were oriented thus before complete solidification of the tonalite. The foliation, therefore, must have been developed, at least partly, before complete solidification.

The only evidence opposing this first hypothesis is that furnished by the petrofabric diagrams. The intersecting surfaces in the rock containing basal planes of biotite and (010) faces of plagioclase are not readily explained, the writer believes, as being the result of primary flow. A wavering of the flow lines is to be expected, but the development of one or more definite surfaces inclined to the foliation is a different matter. Moreover, the optic axes of quartz are oriented in a similar manner. The quartz grains are irregular and are not flattened or elongated in any direction bearing a constant relation to the optic axis. The arrangement of the quartz, therefore, is undoubtedly not the result of fluidal movement in the magma. Furthermore, the optic axes of the quartz grains form a girdle normal to the linear direction in the rock, and, from studies of metamorphic rocks (Sander, 1930), this is believed to mean rotation of the grains in a plane normal to the linear direction. If the orientation of the quartz is a result of post-magmatic deformation, then, since the orientation of the biotite and plagioclase can be correlated with the quartz orientation pattern, may not the arrangement of all of these minerals be the result of deformation following solidification of the tonalite?

(2) Evidence favoring the hypothesis that foliation was developed following solidification of the tonalite is as follows: (a) Orientation patterns of the minerals can be better explained by deformation following solidification of the rock. Much is yet unknown about the process of orientation of minerals during metamorphism, but patterns similar to those presented herein have been found commonly in metamorphic rocks (Sander, 1930). In the diagrams of quartz, a girdle has developed normal to $b$, and distinct maxima occur within this girdle. The actual process by which quartz was oriented is not certain, but the grains undoubtedly rotated about an axis and may have been fractured into needles which were mostly aligned in the shear planes (Griggs and Bell, 1938, p. 17371744). The "segmented" quartz grains described on an earlier page may represent incompletely recrystallized needles. A similar movement on the part of the plagioclase and biotite is shown by presence in the diagrams of $s$-surfaces inclined to the $a b$ plane, as well as girdles. This orientation pattern is believed to be an example of flattening structure (German: Plättung) (Sander, 1930, p. 220), which is a dimensional 
orientation of the grain fabric. In most of the biotite and plagioclase diagrams a strong concentration of the poles of basal planes and (010) faces, respectively, occurs at $c$; or in other words, a large proportion of the grains lies in the flattening surface. This surface represents an $s$-surface developed at a different time, and may be the original $s$-surface in the rock. The elongation of the plagioclase and hornblende parallel to $b$ is also compatible with this hypothesis, for in tectonites, the direction of elongation is most commonly normal to the girdle of quartz and biotite. (b) The inclusions possess the same type of mineral orientation as the tonalite, indicating that both inclusions and the host rock were subjected to the same type of movement and that orientation in each was developed at the same time. The fact that the inclusions do not show a preferred orientation within the plane of foliation but do have a $b$-axis that is parallel to the $b$-axis of the tonalite is additional evidence in favor of the post-consolidation origin not only of the quartz fabric but also of the biotite fabric. (c) In support of the theory that minerals in some igneous rocks have been oriented by post-magmatic deformation, we have results of petrofabric studies made on other intrusive bodies. Johs (1933) examined a quartz porphyry possessing a linear structure parallel to that in a mica schist intruded by the porphyry. A quartz girdle normal to the linear direction is present in both rocks. The direction of lineation in the porphyry is not that to be expected were the mineral orientation produced by magmatic flow. $\mathrm{He}$ concluded that deformation, probably during the final stages of solidification, had played some part in the orientation of the minerals of the quartz porphyry. A granite, which is largely massive, was studied by Maroschek (1935). Even though no linear direction in the rock was megascopically observable, girdles of quartz were found to occur, and these correlated with the joint pattern in the rock as if the granite were a true tectonite. In some of the gneisses studied by Sahlstein (1935), girdles of quartz were found oriented at right angles to the foliation and to the linear direction in the rock, a case similar to that of the Val Verde tonalite.

Opposed to the hypothesis that the arrrangement of the minerals in the tonalite was produced entirely following solidification is evidence furnished by the parallel orientation of flattened inclusions, as discussed under (1.,c).

(3) A third hypothesis explains the structure as having been produced by a combination of flow before, and deformation following, solidification. A time interval between the period of flow of the magma and the period of deformation of the crystallized tonalite is not required. The earlier stage may have graded into the later as the rock increased 
in crystallinity. This combination of the first and second hypotheses is necessary to explain all the phenomena. On the basis of the foregoing discussion it is believed that the foliation and inclusions received their orientation during flow of the partly crystallized magma. Some reorientation of mineral grains occurred, however, as a result of shearing stresses acting on the solid rock. How significant post-magmatic rearrangement of grains may have been is not clear. Rotation of quartz, biotite, and plagioclase crystals in a plane normal to the linear direction in the rock seems to have occurred, but was the $a$-axis of plagioclase (the linear direction in the rock) appreciably shifted in direction, or is the present linear direction the original direction of elongation of the magma? The writer believes there is a possibility that the linear direction is a structure impressed upon the rock during the final stages of, or following, solidification and is possibly independent of the original direction of elongation of the magma. But the fact that the texture of the tonalite is dominantly igneous rather than crystalloblastic is evidence for believing that post-magmatic deformation was not sufficiently intense to disturb primary lineation in the rock.

If we assume that lineation in the tonalite is a primary feature, then development of orientation of the minerals may be viewed from two standpoints depending on direction of intrusion of the magma: (a) The magma was intruded from the northeast up the dip of the schist. Long directions of crystals were arranged parallel to the direction of motion of the magma and flat surfaces were arranged parallel to the contacts with country rock. Deformative stresses, which may have been active in the region during intrusion, took effect on the tonalite after it possessed sufficient rigidity to transmit differential stress. The stresses were of such" a nature that the rock tended to be sheared parallel to the contact and in the direction of the strike, with the resulting rotation of the minerals. The existing foliation in the rock influenced the attitude of the plane of rotation of the minerals to the extent that this plane of rotation was maintained normal to the foliation. The foliation was transformed into a flattening structure by rearrangement of the mineral grains. (b) The magma was pushed in either from the northwest or southeast in a direction parallel to the strike of the country rock. The actual elongation of the magma, however, was up dip, so that a linear direction parallel to the dip of the country rock was developed. That is, a linear direction was developed at right angles to the direction of intrusion of the magma. The same forces that were instrumental in emplacing the magma produced the later rotation of mineral grains about the linear direction in the rock. By thus assuming a horizontal direction of intrusion parallel to the later translation direction in the solid state, the 
coincidence of a later stress being applied normal to an earlier force does not have to be invoked. Furthermore, a horizontal direction of intrusion might explain the small folds and crinkles with axes parallel to the dip of the schist which commonly occur in the schist near the contact and seem to be related to intrusion of the tonalite.

The writer concludes that the foliation developed in the tonalite as a combined result of flow before complete solidification, and of postmagmatic deformation. The $s$-surfaces and girdles may have been produced during the late stages in the crystallization of the tonalite, but it is difficult to understand how $s$-surfaces could have developed if the rock were not essentially solid. The actual amount of post-magmatic movement may have been small. The linear direction now visible within the tonalite probably represents the original direction of elongation of the magma and may be parallel or normal to the direction of intrusion.

The fabric pattern of the tonalite is not present in the schist specimens which were examined. The $a b$ plane in the schist is parallel to that in the tonalite, but the $a$-axis in the schist is parallel to the $b$-axis in the tonalite. If the movement which produced the mineral orientation in the tonalite had similarly occurred in the schist, at least a semblance of a girdle normal to $a$ should appear in the diagrams of the schist. Since this is not the case, it is concluded that movement in the tonalite was localized, that is, confined to the tonalite. The movement probably occurred while the tonalite was more plastic than the schist.

\section{CONCLUSTONS}

The results of micrometric and radioactivity measurements of the Val Verde tonalite may be summarized as follows. (1) The linear method of Rosiwal is accurate to within about one per cent for an individual constituent, in the sense in which per cent is used here. (2) A thin section greater than 300 sq. $\mathrm{mm}$. samples a hand specimen of the tonalite within the limits of error of the measuring method. (3) A hand specimen samples a body of tonalite six feet in diameter probably with an error of less than 3 per cent for one mineral. (4) Micrometric and radioactivity measurements made on samples of tonalite taken along a line extending from the border of the tonalite intrusive to a point 5 miles out in the intrusive have shown that: (a) none of the minerals studied increases or decreases regularly in amount along the line, although orthoclase is slightly more abundant near the border: (b) the albite content of the plagioclase and radioactivity of the tonalite both increase toward the border. Heavy mineral studies have shown that zircon also increases in abundance toward the border. If radioactive substances are contained in zircon, then this mineral may vary in amount directly as the albite 
content of the plagioclase. (5) The more acidic border of the tonalite intrusive is believed to be due to assimilation of quartz-biotite schist. (6) On the basis of mineralogic and radioactivity data it is believed that the dark, fine-grained inclusions in the tonalite are xenoliths of gabbro and quartz-biotite schist.

The geologic history of the district may be divided into five stages. (1) During the Triassic period arenaceous sediments were deposited. (2) Later in the Mesozoic, after burial and consolidation of the sedimentary series, the minerals were recrystallized and the beds folded along axes striking northwest. Shearing parallel to the beds accompanied the folding, rotating the grains about the tectonic axis. (3) Following the folding of the schist and before the Lower Cretaceous, partly crystalline magma entered the schist and assumed a flow structure parallel to its contacts. Assimilation of the schist seems to have been important during emplacement of the intrusive. (4) Either before the rock had become entirely crystalline, or following this stage, horizontal movement parallel to the foliation occurred in the rock, effecting a new orientation for some or all of the minerals in the tonalite. Movement along the strike slip faults that occur within and bordering the Perris Block may have been associated with the horizontal movement in the tonalite. (5) The history of the Perris Block during the Tertiary period is incompletely known and these studies give us no additional information. At present the block appears to be down-dropped with respect to the districts to the north, west, and east, and it is also apparently tilted downward toward the east.

\section{WORKS TO WHICH REFERENCE IS MADE}

Balk, Robert (1937) Structural behavior of igneous rocks, Geol. Soc. Am., Mem. 5. 177 pages.

Dudley, P. H. (1935) Geology of a portion of the Perris Block, southern California, Calif. Jour. Mines and Geol., vol. 31, p. 487-505.

(1936) Physiographic history of a portion of the Perris Block, southern California, Jour. Geol., vol. 44, p. 358-379.

English, W. A. (1926) Geology and oil resources of the Puente Hills region of California, U. S. Geol. Survey, Bull. 768, 110 pages.

Evans, R. D., and Williams, Howell (1935) The radium content of lavas from Lassen Volcanic National Park, California, Am. Jour. Sci., 5th ser., vol. 29, p. 441-452.

Fairbanks, H. W. (1892) Calif. Min. Bur., 11th Ann. Report, p. 106-107 and 111-113.

Fletcher, A. L. (1911) The radioactivity of the Leinster granite, Philos. Mag., vol. 21, p. 102-111.

Goodyear, W. A. (1888) Calif. Min. Bur., 8th Ann. Rept., p. 526-527.

Griggs, David, and Bell, J. F. (1938) Experiments bearing on the orientation of quartz in deformed rocks, Geol. Soc. Am., Bull., vol. 49, p. 1723-1746.

Hirschi, H. (1927) Radioaktivität der Intrusivegesteine des Aarmassivs, Schweiz. Min. u. pet. Mitt., vol. 7, p. 98-114. 
Hurlbut, C. S., Jr. (1935) Dark inclusions in a tonalite of southern California, Am. Mineral., vol. 20, p. 609-631.

Johs, Max (1933) Der Granitporphyr von Thal-Heiligenstein im Thuringer Wald, Tscherm. Min. u. pet. Mitt., vol. 43, p. 283-318.

Joplin, G. A. (1935) Origin of basic xenoliths in plutonic rocks, Geol. Mag., vol. 72, p. 227-235.

Larsen, E. S., and Miller, F. S. (1935) The Rosiwal method and the modal determination of rocks, Am. Mineral., vol. 20, p. 260-273.

Maroschek, E. F. (1935) Beiträge zur Kenntnis des Granites von Mauthausen in Oberösterreich, Tscher. Min. Pet. Mitt., vol. 43, p. 375-405.

Pabst, Adolf (1936) Orientation of minerals in "autoliths", Am. Mineral., vol. 21, p. 68.

Piggot, C. S., and Merwin, H. E. (1932) Radium in racks: IV. Location and association of radium in igneous rocks, Am. Jour. Sci., 5th ser., vol. 23, p. 49-56.

Ransome, F. L. (1932) Final geological report on the Bernasconi and Val Verde tunnel lines, Colorado River Aqueduct, unpublished.

Sahlstein, Th. G. (1935) Zur Regelung der Gesteine im Kristallin von LiverpoolLand in Ostgrönland, Meddelelser om Grönland, vol. 95, p. 1-23.

Sander, Bruno (1930) Gefuegekunde der Gesteine, Julius Springer, Vienna. $3 \check{2}$ pages.

- - and Felkel, E. (1929) Zur tektonischen Analyse von Schmelztektoniten, Sitzungsber. der Heidelberger Akademie der Wissensch., Math.-Nat. KI., vol. 13, p. 1-40.

Schmidt, Walter (1932) Tektonik und Verformungslehre, Borntraeger, Berlin. 208 pages.

Strutt, R. J. (Lord Rayleigh) (1905) On the distribution of radium in the earth's crust, and on the earth's internal heat, Royal Soc. of London, Pr., vol. 77, p. 472-485.

Waring, G. A. (1919) Ground water in the San Jacinto and Temecula basins, California, U. S. Geol. Survey, Water Supply Paper 429, p. 15.

Waters, J. W. (1909) Radioactive minerals in common rocks, Philos. Mag., vol. 18, p. 677-679.

—_ (1910) Radioactive minerals in common rocks, Philos. Mag., vol. 19, p. 903-904.

Wilson, R. W. (1937) Heavy accessory minerals of the Val Verde tonalite, Am. Mineral., vol. 22, p. 122-132.

Geophysical Laboratory, 2801 Upton St, Washington, D. C.

Mandscript received by the Secretary of the Socizty, November 2, 1938. 